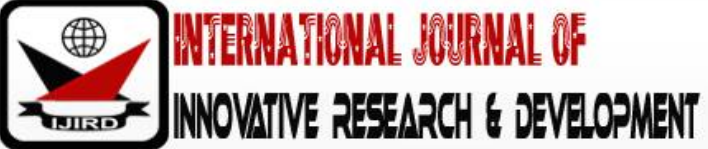

ISSN 2278 - 0211 (Online)

\section{Effect of Banking Sector Clean Up on the Safety of Depositors' Funds}

\author{
Dr. Ebenezer M. Ashley \\ Lead Consultant, Department of Finance, Banking, Economics and Business, \\ Institution name: EBEN Consultancy, Accra, Ghana \\ Dr. Edward Kufuor \\ Chairperson, Department Name: Business, ASA College, New York, USA \\ Daniel Osabutey \\ Senior Lecturer, Department of Accounting and Finance, \\ Accra Technical University, Accra, Ghana \\ Justine Seku \\ Accountant, Department of Accounting and Business \\ EBEN Consultancy, Accra, Ghana
}

\begin{abstract}
:
The financial sub-sector which includes the banking industry is the "engine" that accelerates development and growth in global economies, including Ghana. Throughout the years, a number of laws have been enacted through Ghana's Parliament to bolster activities and performance of the financial sub-sector of the Ghanaian economy. The financial sub-sector forms an integral part of the Services sector. However, there has been a steady decline in growth rate of the Services sector in recent years. The objective of this research was to examine the implications of the banking sub-sector reforms for key stakeholders such as depositors, and the relative effect on their funds. The quantitative approach to scientific inquiry formed the basis for the conduct of this research. A cross-sectional design was adapted and used in the study. This allowed the researcher to gather relevant research data over a specific period of time. Data required for the research were obtained essentially from secondary sources including text books, journals, research papers, newspaper publications; electronic databases of the Bank of Ghana, Google Search Engine, Index Mundi; and financial websites such as Tradingeconomics.com, among others. Descriptive statistics and regression models were used to describe the research variables; and to evaluate their behaviour over the stated time frame in the Ghanaian banking sub-sector. The research findings revealed a negative relationship between banks and specialised deposit-taking institutions that are in distress and failing(independent variable) and the safety of depositors' funds (dependent variable).The findings revealed the independent variable accounts for only about $23 \%$ of the variation in the dependent variable. The results suggested about $77 \%$ of the outcome is explained by external random factors such as measures put in place by the Bank of Ghana to mitigate risks associated with depositors' funds. The findings lend credence to the financial ingenuity of the Bank of Ghana aimed at stabilising the banking system; and enhancing its contribution to national socio-economic development and growth. The study recommended the need for the Bank of Ghana to maintain separate departments responsible for ensuring market-stability and market-integrity of all financial institutions under its supervision; and establish an insurance reserve to expedite mitigation of liquidity and solvency challenges. Corporate benchmarks of financial institutions must be preceded by due diligence and appropriate analysis. Management's emphasis should be on effective operational risk management, not on investment strategy. Struggling banks with little or no evidence of survival must be liquidated early to avoid further financial tsunami; and to ensure financially healthy and competitive banks are maintained in the economy.
\end{abstract}

Keywords: Amendment, banking act, corporate governance, depositor, financial institution, merger and acquisition, risk tolerance

\section{Introduction}

The Ghanaian economy revolves around three main sectors. These include the agricultural, industrial, and services sectors. The banking industry remains a sub-sector of the services sector of the Ghanaian economy. Undoubtedly, the financial system remains the pivot around which every economy is nucleated. Stated differently, the financial subsector (which includes the banking industry or sub-sector) is the "engine" that accelerates development and growth in global economies, including Ghana. 
Key stakeholders in the banking sub-sector include government regulatory bodies such as the Bank of Ghana (BoG), Securities and Exchange Commission (SEC), and Pensions Regulatory Authority (PRA); shareholders; bondholders; and depositors. In spite of their affinity with numerous government agencies, the dominant government body, throughout the world, that relates directly and regulates the activities of banks is the central bank (in the case of Ghana, it is called the Bank of Ghana).

Throughout the years, a number of laws have been enacted through Parliament to bolster activities and performance of the financial sub-sector of the Ghanaian economy. Some of these include the Financial Administration Act of 2003, Act 654; Internal Audit Agency Act of 2003, Act 658; Payment Systems Act of 2003, Act 662; Public Procurement Act of 2003, Act 663; Long-Term Savings Scheme Act of 2004, Act 679; Venture Capital Trust Fund Act of 2004, Act 680; and Foreign Exchange Act of 2006, Act 723, among other enactments (Bank of Ghana, 2007).The following section presents a brief explanation on each of the foregoing Acts.

The Financial Administration Act of 2003, Act 654, received a Parliamentary assent on 28 th August, 2003; and was gazetted on 31st October, 2003. Contents of this Act stipulate powers, responsibilities, and duties of the Finance Minister; appointment and duties of the Controller and Accountant-General, and Deputy Controller and Accountants-General; define public funds including consolidated and contingency funds as well as other funds that may be established by or under an Act of Ghana's Parliament; revenue and other monies to be paid into the consolidated, contingency, and other special funds; custody of public monies and monies received in trust for the Government of Ghana; payment for services rendered by government departments; receipt and payment of deposits; conditions for deletion of government claim from the accounts, and for payments from the consolidation fund; appropriation of public funds, charges on appropriation and orders for disbursement; conditions for payment of work done and contracts; conditions for which government contracts may be entered into; modalities for payments to be effected from the consolidated fund; lapse of balance of appropriation unexpended at the end of the financial year; conditions under which public funds would be invested in securities; conditions for advances and loans from the consolidated fund; condition for investment of the consolidated fund in equity capital of another company; presentation of estimates of revenues and expenditures at least one month before the end of the financial year; expenditure in advance of appropriation; duration of appropriation and warrants; tax revenue and nontax revenue, among other considerations (Bank of Ghana, 2007).

Ghana's Internal Audit Agency was established to serve as a central agency responsible for the co-ordination, facilitation, monitoring, and supervision of internal audit activities in government ministries, departments, and agencies (MDAs); and metropolitan, municipal, and district assemblies (MMDAs) to assure quality in the audit of the foregoing State institutions. In order to secure a statutory backing for its functions, the Internal Audit Agency Act of 2003, Act 658 was enacted, assented to by Parliament, and gazetted on 31st December, 2003. This enactment makes provision for the establishment, objectives, and identified functions of the Internal Audit Agency; establishment of the Internal Audit Board, which is the governing body; composition of board membership by the President in consultation with the Council of State; functions, tenure of office, and allowance of board members; disclosure of interest by board members; appointment of committees by the board; appointment of a Director-General by the President; functions, independence, and powers of the director-general; establishment of internal audit units; action to be taken by the Agency based on the examination of internal audit reports; establishment of professionalism and competence, integrity and confidentiality; maintenance of proper books of accounts, records, and audits; funding of the Internal Audit Agency; submission of annual report to the President; regulations for effective implementation of Act 658; offences and penalties; interpretation of key terms, and transitional provision.

The Payment Systems Act of 2003, Act 662 comprises 26 Sections and sub-sections. Like the preceding enactment, Act 662 was assented to by Parliament and gazetted on 31st December, 2003. This legislative instrument was introduced to ease payments and transfers between and among financial institutions; and between accounts of depositors. Act 662 defines the role of Bank of Ghana in the establishment, promotion, operation, and supervision of fund transfers, payments, settlement and clearing system, subject to such rules as it may publish; modalities for resolution of systemic risk by the Bank of Ghana; retention of payment systems records for a minimum of six years; adherence to transparency principle; full disclosure before and after transfers from the financial institution to the customer; negotiation rights of parties to a transfer transaction; release of transfer funds to beneficiary on time; non-payment of compensation due to delay in the release of transfer funds to beneficiary; obligation to transfer full amount, and to refund in the event of non-execution; irrevocability of executed transfers unless otherwise stated; conditions for application of netting agreements and netting rules; collateral for obligations payment and settlement; disputes settlement; electronic elements (such as floppy disc, hard disc, computer print-out, hard copy, microfilm, among other media) to be admitted as evidence in a court of competent jurisdiction in a case related to transfer; discretion of the court to weigh the evidence; right of Bank of Ghana to make regulations to ensure effective and efficient supervision of established and designated financial systems; conditions for commission of an offence in a transfer; interpretation of key terms; and transitional and saving provision.

On 31st December, 2003, the Parliament of Ghana assented to the Public Procurement Act of 2003, Act 663 to pave way for establishment of the Public Procurement Board, execution of institutional and administrative arrangements for procurement stipulation of tendering procedures, and provision for purposes related to the foregoing. Act 663 was gazetted on 31st December, 2003. It comprises 99 Sections and sub-sections, and categorised into nine parts. Part I presents information on the Public Procurement Board; objective, functions and membership of the board; terms of office, meetings, and appointment of committees by the board; proper books and records keeping for accounts and audit; implementation of a financial year exactly as Government's financial year; and board's submission of annual written report to the Finance Minister. Part II explains the procurement structures. These explanations are captured in Sections 14 through 20 and their sub-sections. Rules related to procurement are presented in Part III. Details in this part are outlined 
in Sections 21 through 34 and their related sub-sections. Part IV discusses approved methods of procurement. These methods are stated in Sections 35 through 43 and their sub-sections. Procedures for tendering, including invitation of tenders and application to qualify, national competitive tendering, among other considerations, form the basis for discussion in part V. Sections 44 through 65 capture the details in this part. Methods and procedures to procure consultants including notice to the general public to express interest in a particular procurement, and short listing of applicants form the basis for discussion in Part VI. Details in this part are expressed in Sections 66 through 77 and their attendant sub-sections. Part VII provides explanation on the right of a contractor supplier or contractor to seek review in times of loss, injury or breach of a procurement contract. Content of Sections 78 through 82 and their sub-sections elucidates this provision. Issues related to disposal of stores, plant and equipment, including authority to dispose are addressed in Part VIII. Sections 83 and 84 and their attendant sub-sections outline the details contained in this part. Part IX presents miscellaneous provisions, including instructions and guidelines for disposal of unserviceable stores, among others.

The Long-Term Savings Scheme Act of 2004, Act 679, was established by an Act of parliament on $11^{\text {th }}$ November, 2004; and gazetted on 12 $12^{\text {th }}$ November, 2004 to provide a broader framework for the operation and regulation of the scheme; and to make provision for related matters. Sections and sub-sections under this enactment stipulate the establishment of the scheme and its regulatory Agency; objective of the scheme; functions of the Agency; power of the Agency to formally request for records from funds managers, trustees, employers, or persons; the Agency's power to conduct inspection and investigation on grounds of suspicion, dishonesty, and fraud, among other offences; formation of a Governing Council and its defined powers; appointment and tenure of office of members on the Council; meetings and formation of committees by the Council; Council members' disclosure of interest in a matter under consideration; Council members' allowances; sources of funding for the Agency and fees; appointment of an Administrator and his or her responsibilities; appointment of other staff, and delegation of power of appointment; keeping proper records for accounts and audits purposes; submission of annual report to the Finance Minister; maintenance of a financial year just like the Government's financial year; plan contributions, and withdrawal of portfolio; provision for a contributor leaving employment; right of a contributor to divert plan, and creation of encumbrances in respect of contributions; duties of employers in relation to the plan; tax reliefs, management of funds and qualifications of a fund manager; duties and powers of a trustee, resolution of disputes, and others.

Venture capital remains one of the significant sources of funding for small- and medium-scale enterprises across the globe. To ensure its official recognition as a viable investment source, and facilitate funding for small- and mediumscale enterprises in some identified sectors of the Ghanaian economy, the Venture Capital Trust Fund Act of 2004, Act 680, was promulgated. This Act received Parliamentary assent on 17th November, 2004. This enactment makes provision for the establishment of the Venture Capital Trust Fund, its objectives and sources of funding; establishment of Board of Trustees and management of the fund; functions and tenure of office of board members; disclosure of interest by board members; allowances for board members; disbursements from the Trust Fund; eligibility of a venture capital financing company to apply for funding from the Trust Fund; management of equity and credit accounts; tax incentives; submission of reports by venture capital financing companies in periods as may be determined by the Finance Minister in consultation with the Board of Trustees of the fund; appointment of an administrator and his or her functions; submission of annual reports, interpretation of key terminologies, and amendments to the Financial Institutions (Non-Banking) Law, P.N.D.C. Law 328 of 1993.

In 2006, the Foreign Exchange Act, Act 723, was enacted and assented to on 29th December, 2006 by Parliament to regulate activities in the Ghanaian currency market. This Act comprises thirty Sections and sub-sections. Specifically, contents of Act 723 stipulate the licensing, regulatory, and supervisory rights of the Bank of Ghana; responsibility of the Bank of Ghana in the implementation of Act 723; licence requirement and the licence application process; conditions for granting and refusing licence issuance; maintenance of a register of licenses; non-transferability and renewal of licenses; conditions for suspension and revocation of licence; notice of suspension, revocation or variation of licence; review and appeal against suspension, revocation or variation of licence; conclusion of foreign exchange business and international payments through a bank or authorised money transfer dealer; condition for requirement of Bank of Ghana's permission prior to payment or transfer of foreign currency; power of the Bank of Ghana to regulate transfers and foreign exchange business between residents and non-residents; powers of the Bank of Ghana to impose restrictions on the export and import of foreign exchange; conditions for engaging in foreign exchange transfer business, and imposition of temporary restrictions on same; provision of information by licensed institutions to the Bank of Ghana to ensure effective supervision and monitoring; provision of information by persons to affirm compliance or detect offences in contravention of Act 723; court orders and admissibility of evidence; search and seizure of property; written notice and reasons for seizure of property to affected owner; recovery, forfeiture and retention of seized property; general prohibitions, offences, general penalty and regulations; interpretation and modification of existing enactments; and repeal, savings and transitional provisions (Bank of Ghana, 2007).

\subsection{Background of the Study}

Since independence in 1957, Ghana has evolved in her quest to develop laws and acts to regulate and improve on the activities of institutions in the banking and financial sub-sector. Laws pertaining to the banking and financial subsector from 1961 through 1998 were compiled and published in 2001. This publication harnessed all banking and financial laws to ease reference by various stakeholders. Overtime, the existing banking and financial laws were reviewed; and new laws were passed between 1998 and 2006. The banking and financial laws relating to 1998 through 2006 complemented the earlier laws by accommodating modifications in the financial system; they encouraged the enactment 
of new rules and regulations in the banking and financial sub-sector across the globe, with strong emphasis on the Basel Committee. The following section presents a brief discussion on various laws enacted in Ghana over the past two decades to regulate the activities of institutions in the banking sub-sector.

\subsubsection{Bank of Ghana Act of 2002 (Act 612)}

Law relating to the functions and activities of the Bank of Ghana was amended and consolidated by the Parliament of Ghana in 2011. On 24th January, 2012, the Parliament of Ghana assented to the amendment and consolidation, and the document was gazetted on 25th January, 2002.It was the 612 th Act of Ghana's Parliament. This working document is known as the Bank of Ghana Act (Act 612). The Bank of Ghana Act (612) is categorised into nine parts. Each part spells out clearly, the functions and responsibilities of the Bank of Ghana. Part one comprises Sections 1 through 7 and their related subsections. This part emphasises on the principle of continuity, that is, the continuous legal existence of the Bank of Ghana; its ability to sue and be sued under its legal seal and name; and its ability to enter into a business contract or transaction as it may deem expedient on behalf of the State. Further, part one outlines the objectives, functions, and authorised shares of the Bank of Ghana; maintenance of a general reserve fund, and payment into consolidated fund; and revaluation of accounts of the Bank of Ghana (Bank of Ghana, 2007).

The administrative functions of the Bank of Ghana are highlighted in Part two. Generally, part two includes Sections 8 through 27 and their related sub-sections. This part explains the formation and composition of Bank of Ghana's Board, functions and policy formulation of the board, board members' terms and condition of service, required qualifications, conditions under which a member shall be removed from the board, how a vacancy on the board could be filled, organisation of board meetings, appointment of various committees to advise the board, appointment of audit committee, governor and deputy governors; functions and emergency powers of the governor; functions of the deputy governors, secretary, chief internal auditor, and other officers and employees of the Bank of Ghana. In addition to the foregoing, part two states conditions under which the governor, deputy governor or an employee would sign a document for and on behalf of the Bank of Ghana; declaration of secrecy by Bank of Ghana employees in all designations; employee's liability for loss or damage suffered by the Bank of Ghana due to the former's negligence or willful default; and establishment of the Monetary Policy Committee (MPC) (Bank of Ghana, 2007).

The role of the Central Bank as the fiscal agent of Ghana Government and its related institutions is outlined in Part three. Sections 28 through 32 and their attendant sub-sections form the nucleus of this part. Specifically, part three depicts the Central Bank's role as the custodian of state funds within and outside Ghana; role as government's banker, that is, responsible for bullion, securities, receipt, collection, payment and remittance of money on behalf of the State; temporary advances to the State; management of public debt; and an advisor to government on fiscal matters (Bank of Ghana, 2007).

Part four of Act 673 is centred on Sections 33 and 34 and their related sub-sections. As part of its responsibilities, the Bank of Ghana is required to ensure effective credit control. Part four of the Bank of Ghana Act (Act 612) elucidates this responsibility. Here, the Bank of Ghana is obliged to report movements in money supply which it considers unusual and suspicious. The Central Bank has the obligation to manage Ghana's monetary and banking system, including review of banking institutions' minimum capital adequacy ratio (Bank of Ghana, 2007).

Powers of the Bank of Ghana in domestic operations are defined in Part five. This part is extended to include Sections 35 through 49 and their related sub-sections. Part five spells out the prerogative of the Central Bank to issue and redeem coins and notes in Ghana; its ability to hold assets to cover coins and notes issued; determination of assets to be used as currency cover; maintenance of currency cover to meet Central Bank's liability relative to the amount of coins and notes issued; determination of the unit, denomination, and form of currency to be issued in Ghana; definition of Bank of Ghana's business transactions, including accepting deposits and making payments on behalf government institutions, agencies, and other international bodies; appointment of other banking institutions as agents for the issue, re-issue, exchange and withdrawal of approved national currency coins and notes based on agreed terms between the Central Bank and the agent; determination of currency's face value and purpose as a legal tender; and conditions under which mutilated coins or notes or both may be exchanged by the Central Bank. Further, it is the Central Bank's responsibility to prove the imitation of Ghana's coins or notes or both when necessary in court proceedings; and exchange currencies from persons without charge. This part affirms Bank of Ghana's exemption from payment of stamp duty on coins and notes issued; involvement in securities transactions, clearing houses; and businesses it may not engage in such as purchase of shares in non-financial institutions. However, the Central Bank could engage in the foregoing when authorised by the Board; and the underlying objective is to lend credence to or support its core functions (Bank of Ghana, 2007).

Bank of Ghana's mandate to be actively involved in foreign operations is stated in Part six. Content of part six includes Sections 50 through 53 and their related sub-sections. This part affirms Bank of Ghana's ability to trade in assets of international value such as buying and selling external convertible currencies, among others; ability to borrow money from foreign institutions up to ninety (90) days and guarantee without prior approval from the sector Minister; ability to formulate exchange rate policy in consultation with the sector Minister; and function as custodian of Ghana's foreign exchange (Bank of Ghana, 2007).

One of the integral departments of the Bank of Ghana is the Banking Supervision Department. This department is responsible for supervising the activities of all financial institutions in the country. The mandate of Bank of Ghana's Board to appoint an officer to head this department; the Central Bank's responsibility to provide statistical data, and publish bulletins and reports; and conditions under which the Bank of Ghana could request for information from individuals and institutions to facilitate its conduct of authentic and reliable research are contained in Part seven of Act 673. Specifically, the foregoing details are traced to Sections 54 through 56 and their related sub-sections (Bank of Ghana, 2007). 
The Bank of Ghana is required to keep records of all transactions and maintain books of accounts which shall be audited by the Auditor-general or any other auditor appointed by the former. Information on the Central Bank's general returns, foreign exchange returns, and financial year book, together with the preceding information is disclosed in Part eight. This part of Act 673 comprises Sections 57 through 61 and their related sub-sections (Bank of Ghana, 2007).

Part nine states Bank of Ghana's ability to organise training programmes for its employees and banking institutions licensed in Ghana. Details of this part include Sections 62 through 70 and their related sub-sections. The training programmes may be organised by the Bank of Ghana in co-operation with licensed banks or any other bodies the Bank of Ghana Board may deem appropriate. This part states, categorically, the Central Bank's exemption from income tax payment; and shield from liquidation unless a special legislation is passed for that purpose. Legal instruments required to facilitate functions of the Central Bank are outlined in part nine. These include bye-laws, regulations, offences and resultant penalties; interpretation, repeals and savings (Bank of Ghana, 2007).

\subsubsection{Banking Act 2004 (Act 673)}

Act 612 of the Bank of Ghana Act of 2002 affirms the functions and responsibilities of the Central Bank in the efficient and effective functioning of Ghana's financial system. However, Act 673 of the Banking Act of 2004 was introduced as an amendment to Act 612 of the Bank of Ghana Act of 2002; the former was introduced to consolidate the latter; and to ensure the existence of adequate and relevant laws to regulate the activities of various banks in Ghana. The Bank of Ghana Act (Act 673) was assented to on 29th January, 2004, and gazetted on 29th October, 2004. Akin to the Bank of Ghana Act (612), Act 673 is grouped into nine parts. Each part outlines the responsibilities of the Bank of Ghana and banks incorporated within the jurisdiction of Ghana (Bank of Ghana, 2007).

Part one is made up of Sections 1 and 2 of Act 673 of the Bank of Ghana Act of 2004. This part states how the Companies Code of 1963, Act 179, could be applied to the establishment of banks in Ghana; and how the content of the Bank of Ghana Act (673) shall prevail in times of conflict or inconsistency, relative to the Companies Code of 1963, Act 197. This part elucidates the regulatory and supervisory authority of the Bank of Ghana over all licensed banks, including promotion of an effective banking system, and addressing unlawful bank practices, among others (Bank of Ghana, 2007).

Sections 3 through 22 of Act 673 and their related sub-sections constitute Part two. The licensing eligibility of corporate bodies for the establishment of banks in Ghana is explained in part two. This part indicatesonly corporate bodies are eligible to be licensed to perform banking functions in Ghana; it is unlawful to operate a bank business without a licence, sanctions apply to such an act; an application for a licence must be submitted to the Bank of Ghana, accompanied by all relevant documents including the type of bank to be established, names, addresses, and occupations of shareholders, and so forth. The Bank of Ghana reserves the right to issue a provisional licenceto the applicants when they exude integrity and professional competence, and minimum capital requirements are met, among other considerations. A bank incorporated in Ghana may invite the general public to subscribe to its shares after it has been issued with a provisional licence by the Bank of Ghana. The Bank of Ghana may issue a final approval and licence when the bank meets all conditions necessary to ensure its efficient and effective operation in the country. Conversely, an application for a licence may be refused if the necessary conditions are not met satisfactorily by the applicants. The Bank of Ghanais required by law, to communicate its decision on an application not later than three months after the submission of a complete application. Services to be provided by banks to their customers as well as restrictions on banks' direct engagement in immovable property, commercial, industrial and agricultural activities are clearly defined in this part. Further, this part explains the conditions for revocation of issued licence, procedure for revocation, and the imposition of a moratorium on payments following the revocation of a bank's licence; application of the word, "bank," to only a banking institution; the right of the Bank of Ghana to inspect any financial institution it suspects of providing banking services without a licence; the need for banks to display their licences and operate in places 'approved' by the Bank of Ghana; and conditions under which foreign banks shall operate representative offices in Ghana. Finally, any licensed bank that seeks to make amendments to its existing regulations must seek prior approval from the Bank of Ghana (Bank of Ghana, 2007).

The capital and reserves requirements of bankslicensed in Ghana are stated in Part three. This part outlines the capital adequacy ratio of licensed banks - each bank is expected to maintain a capital adequacy ratio of ten percent (10\%), and so on; the need for additional capital to mitigate special risks; the need for a bank to compute minimum capital adequacy ratio on consolidated basis when it maintains a subsidiary or subsidiaries; the need for the Bank of Ghana to notify defaulting banks of non-compliance with the minimum capital requirement, and penalties thereof. Part three states the right of the Bank of Ghana to merge, liquidate or takeover a bank experiencing persistent capital adequacy ratio crisis with a bank that is financially healthy; the need for a licensed bank to transfer part of its operating profit to the Reserve fund; and conditions under which a bank shall declare dividend such as complete write-off of all its capitalised expenditure. Sections 23 through 30 of Act 673 and their related sub-sections constitute part three (Bank of Ghana, 2007).

Part four outlines how banks could maintain a portion of their assets in a liquid form to meet operational needs; Bank of Ghana's notification to defaulting banks for non-compliance with minimum liquidity requirement, and penalties thereof including payment of interest to the Bank of Ghana, among others. This part comprises Sections 31 through 33 of Act 673 and their related sub-sections (Bank of Ghana, 2007).

Part five of Act 673, Bank of Ghana Act, 2004 includes Sections 34 through 40 and their related sub-sections. Ownership and control of a licensed bank, including holding of significant ownership shares; or transfer of shares that may have a significant effect on shareholdings and ownership structure are explained, explicitly, in part five. This part states the right of the Bank of Ghana to disapprove of the transfer of significant shareholdings to a person whose influence may not inure positively to the bank's management and operations; and the right of the Bank of Ghana to approve of transfers of, and changes to existing controlling interests of licensed banks, and penalties for non-compliance. Further, this part 
indicates the condition under which a person may not qualify to be an employee, officer or a director of a bank; disclosure of interest by directors; prior notice to the Bank of Ghana in the appointment of managing directors and deputy managing directors by banks; and the need for the foregoing appointees to be resident in Ghana (Bank of Ghana, 2007).

Restrictions on a licensed bank's lending and investments are spelt out in Part six of Act 673. Sections 41 through 50 and their related sub-sections constitute part six of Act 673. This part states the limit to financial exposures (not more than $25 \%$ of net own funds) to a person or group of persons; written approval of the Bank of Ghana prior to unsecured financial exposure to a bank's directors and significant shareholders; the bank's lending limit to its officers and employees (not exceeding two years' salary);requirements for lending to related parties such as creditworthiness of the person to whom the loan is advanced; prior approval of the Bank of Ghana to the establishment of subsidiary companies, and limits on equity investment in subsidiary companies (not more than 15\% of net own funds); limits on investment in other institutions (not more than 10\% of net own funds); the need for the bank to report large financial exposures to the Bank of Ghana; and the power of the Bank of Ghana to vary the prudential limits for all licensed banks, or a particular bank for a period the former deems appropriate (Bank of Ghana, 2007).

Generally, Part seven covers Sections 51 through 69 and their related sub-sections in Act 673 of the Bank of Ghana Act of 2004. Bank of Ghana's powers to supervise and control all banks licensed in the country are stipulated in part seven. Bank of Ghana's regulations and directives to all licensed banks; periodic submission of information or data on a bank's assets, liabilities, income, expenditure, and any other valuable data to the Bank of Ghana, and imposition of fines for noncompliance; the right of Bank of Ghana to carry out an on-site examination of a bank without prior notice; the right of onsite examiners to review the books of the implied bank; the powers of Bank of Ghana to investigate or scrutinise a bank without prejudice; the right of Bank of Ghana's representative (examiner) to take custody of the requested books after a written notice to the implied bank; the right to verify information contained in the bank's books through audit; preparation of on-site examination report and presentation of a copy to the implied bank; issuance of directive to the examined bank to take remedial actions based on the report's findings, and the need for the bank to comply; the need for each bank director and official to co-operate with the Conservator in the discharge of his or her responsibilities as enshrined in Act 679; conditions under which the Bank of Ghana shall revoke the licence of a bank; issuance of a formal notice of revocation to the affected bank, and its ability to submit a formal explanation within a specified period; Bank of Ghana's right to issue a final order after examining a bank's books and reviewing submitted explanations; imposition of a moratorium pending a decision on the future set up of a bank saddled with strong financial challenges; the affected bank's ability to appeal to the Finance Minister against orders of the Bank of Ghana within fourteen days from the date of receipt of Bank of Ghana's order; surrendering of a bank's licence to the Bank of Ghana following revocation of same; and Bank of Ghana's right to appoint a Liquidator to wind up the affairs of the affected bank. This is notwithstanding provisions of Act 180 of the 1963 Act on Bodies Corporate, specifically, Official Liquidations; and conditions under which a bank may voluntarily wind up (Bank of Ghana, 2007).

Part eight of Act 673 of the Bank of Ghana Act of 2004 covers Sections 70 through 81 and their related subsections. This part focuses on the accounts and audits of licensed banks. This part affirms Bank of Ghana's ability to issue guidelines to banks on acceptable accounting policies and practices, presentation of annual accounts and disclosure of key information in the annual accounts; the need for the bank to keep accurate and reliable accounting records, and financial statements; release of a bank's accounting records for audit by qualified auditors duly appointed in accordance with provisions of Act 673; conditions which would necessitate Bank of Ghana's appointment of auditors to a bank; determination ofremuneration of an auditor, auditor's right to information, and auditor's report; Bank of Ghana's right to request for special audit and additional information at the expense of the implied bank; conditions under which the Bank of Ghana would request for the termination of an auditor's appointment; and the need for a bank, throughout the year, to display in a conspicuous place, a copy of its audited financial statements (Bank of Ghana, 2007).

Other relevant provisions ofAct 673 which are not presented in the preceding parts are contained in Part nine. This part encapsulates Sections 82 through 92 of Act 673, and their related sub-sections. The part discloses Bank of Ghana's prohibition of floating charge by a licensed bank; the need for bank directors and officers to keep their bank's information secret, and only divulge same as required by law or in a Court of competent jurisdiction; as authorised by a customer; as required by the Bank of Ghana, or in the interest of the implied bank; Bank of Ghana's right to consolidate and disclose information it obtains from the banks to the general public when it deems fit, and believes it is in the public interest to act same; the need for the Bank of Ghana to submit to the Finance Minister a trend and progress report on banking within one hundred and twenty days after the end of its financial year; conditions under which Bank of Ghana officials would be protected against actions and claims; offences, joinder of offences, and penalties of Bank of Ghana officials; interpretation of key terms; repeal of Banking Law of 1989 (P.N.D.C. Law 225); and validity of existing licences prior to the commencement of this Act, and compliance to same (Bank of Ghana, 2007).

\subsubsection{Banking (Amendment) Act of 2007 (Act 738)}

As noted in the preceding section, Act 673 of the Banking Act of 2004 was introduced to ensure the existence of adequate and relevant laws to regulate the activities of various banks in the country. The dynamism characterising activities in the global financial sector made it imperative for Ghanaian law makers to review and amend, where necessary, some sections of the existing laws regulating the operations of financial institutions incorporated in Ghana. The foregoing culminated in the passage of the Banking (Amendment) Act of 2007, Act 738. This Act (Act 738) received Parliamentary assenton $18^{\text {th }}$ June, 2007, and was gazetted on $22^{\text {nd }}$ June, 2007. 
The Banking (Amendment) Act of 2007, Act 738,was introduced to ease the establishment of Ghana's International Financial Services Centre. Responsibilities of this Centre include attracting foreign direct investment (FDI) to the country; mobilising income from licence fees payable in foreign currency denominations; creating employment opportunities; enhancing local knowledge and skills in the financial sub-sector; strengthening the financial sub-sector by expanding and improving on use of investment banking instruments across the country (Bank of Ghana, 2009, p. 30). Act 738 of 2007 includes amendments to Sections 1 through 5 of Act 673 of 2004, and insertion of Sections 5A, 5B, and 5C of Act 673; amendments to Sections 6 through 9 of Act 673; and amendments to Sections 12 through 14 of Act 673. The following sections of Act 673 are also amended: Sections 16, 17, 23, 29, 33, 37, 38, 40, 42, 46, 51A, 60A, 62, 69A and 69B, 72, 74, 83, 84, 84A, 87, 89A and 89B, and 90. Further, Act 738 includes an insertion of First, Second, Third, and Fourth Schedules to Act 673 (Bank of Ghana, 2009, p. 29).Act 738 involves amendments and insertions to 35 of the 92 Sections in Act 673; Act 738 comprises about 38.04\% of all the sections contained in Act 673.

Inserted Sections 5A, 5B, and 5C indicate the types of banking licence categories to which a banking business may belong: General Banking licence, Class I Banking licence, or Class II Banking licence. They outline limitations of Class II Banking licence holders; and pre-requisites for issuance of a licence.

The Bank of Ghana's power to vary licensing conditions through a formal (written) notice to the implied banking institution is expressed in inserted Section8A.The insertion of Section 51A helps to provide guidelines for levying of charges and payment of fees under Act 738. Inserted Section 60A explains the right of the Bank of Ghana to appoint a competent adviser to the chief executive of a bank after examining the bank's explanations; and deeming it necessary to appoint same to help improve the operations of the affected bank. Appointment of the competent adviser is at the expense of the implied bank. Under Act 738, the word, "Voluntary," captured in Section 69 of Act 673is deleted while Sections 69A and 69B are inserted. Section 69A emphasises the priority in the settlement of deposit liabilities in times of bank insolvency or suspension of payments, among other unfavourable operational conditions while Section 69B outlines priority in the settlement of deposit liabilities when banks issued with Class I and Class II licenses are winding up. Section 84A of Act 673 as inserted, allows banks licensed in Ghana to liaise and enter into agreements with international agencies or foreign supervisory institutions responsible for the supervision of banks or similar institutions to exchange information for the purpose of enhancing the operations and performance of the former. Protection of information confidentiality by the foreign supervisory institution is vital to the success of the relationship between both parties.

Section 89A of Act 673 as inserted spells out how Class II licensed banks could open and maintain an account in Cedis with a bank issued with a Class I Banking licence or General Banking licence for payments of salaries, remuneration, penalties, fines, fees, and other local payments (Bank of Ghana, 2009, p. 52). Section 89B of Act 673 as inserted, indicates exemptions to payments by holders of Class II Banking licence, including payment of fees, duty, levy charge, and tax as specified in the Fourth Schedule of Act 738.

Act 673 as amended includes First, Second, Third and Fourth Schedules. This appears in Section 36 of Act 738.The First Schedule outlines the categories banks, types of licence, and the minimum paid-up capital required after accumulated losses have been deducted. The Second Schedule shows the statements of confidentiality by the appointed Chairperson of the Board of Directors. This Schedule has two parts: Part One depicts content of the oath of confidentiality; Part Two reveals details of the declaration of confidentiality. The Third Schedule reveals confidentiality statements by the appointed Chief Executive Officer of the bank. This Schedule has two parts and contents similar to the Second Schedule; the only difference lies in the signatories. The Fourth Schedule includes excerpts of the Value Added Tax Act of 1998, Act 546; Internal Revenue Act of 2000, Act 592; Financial Administration Act of 2003, Act 654; Stamp Duty Act of 2005, Act 689; and other Acts specified by the sector Minister (Bank of Ghana, 2009, p. 58).

\subsubsection{Bank of Ghana (Amendment) Act of 2016 (Act 918)}

Management and technological evolution in the banking sub-sector make it imperative for existing banking laws regulating the sub-sector to be constantly reviewed to be abreast of changing and current trends. To this end, in 2016, some sections of the Bank of Ghana Act of 2002, Act 612, were amended to improve the content; and to meet international standards in banking supervision. Thus, the Bank of Ghana (Amendment) Act of 2016 was promulgated in furtherance of the Bank of Ghana Act of 2002, Act 612.

The Amended Act of 2016 was passed by Parliament and received Presidential assent on 19th August, 2016. The new amendment affected twenty existing Sections while seven new Sections were inserted. Specifically, the following Sections of Act 612 were amended: 3, 4, 8, 10, 11, 12-14, 17, 22, 27, 29, 30, 49, 50, 53, 54, 69, and 612.The following Sections were inserted into Act 612: 2A, 11A, 34A, 46A, 53A, 57A, and 68A (Bank of Ghana, 2016a, p. 2).

Inserted Section 2A of Act 612 allows the Bank of Ghana to establish departments and administrative structures to enhance its supervision and service delivery in the area of banking and related functions. Section 11A of Act 612 as inserted, explains conditions under which a member could be disqualified from serving on the Bank of Ghana Board. The newly inserted Section 34A of Act 612 affirms the sector Minister's ability to authorise the Bank of Ghana, through the Controller and Accountant General, to invest any remaining credit to Government Account or the Consolidated Fund.

The introduction of Section 46A of Act 612 permits the Bank of Ghana to provide emergency liquidity assistance to licensed banks, savings and loans companies or other financial houses after determining the implied financial institution is illiquid, but solvent; and prescribing terms and conditions for same, among others. Inserted Section 53A of Act 612 obliges the Bank of Ghana to submit a report on the conduct of its activities to the Parliament of Ghana once every six months: the first report must be submitted by the end of July of the year while the second report is expected by the end of February of the following year. Section 57A of Act 612 as inserted stresses the need for the Bank of Ghana's financial statements to be prepared and presented in accordance with international financial reporting standards adopted by the Board. The inserted 
Section 68A of Act 612 affirms the prevalence of Act 612 over any other enactment in times of conflict between the former and latter in matters related to banking; and other banking related matters (Bank of Ghana, 2016a, pp. 2-14).

\subsubsection{Banks and Specialised Deposit-Taking Institutions Act of 2016, Act 930}

The Banks and Specialised Deposit-Taking Institutions Act of 2016, Act 930, has one hundred and sixty (160) Sections and two (2) Schedules. This Act was passed by Parliament as an amendment to and consolidation of existing laws related deposit-taking; provision of a strong regulatory framework for institutions engaged in the business of deposittaking; and to make a strong regulatory provision for other matters related to banking. This Act was assented to by the President of Ghana on 14th September, 2016. Act 930 of 2016 can best be described as a synthesis of Acts 612 of 2002,673 of 2004, 738 of 2007, and 918 of 2016; and amendments to some Sections and sub-sections of the foregoing Acts.

Contents of Act 930 of 2016 are categorised into the following sub-themes: preliminary matters, licensing of banks and specialised deposit-taking institutions, capital and reserves, liquidity, ownership and control, restrictions on lending and investments, accounts and audit, powers of supervision and control, official administration, receivership and liquidation, and miscellaneous provisions. The Act concludes with two Schedules: First Schedule and Second Schedule. The First Schedule contains an oath of confidentiality to be taken by persons appointed to the positions of director, head of department, officer or employee at the Bank of Ghana. Contents of the Second Schedule relate to declaration of confidentiality by the foregoing persons. The oath of confidentiality and declaration of confidentiality shall be taken by the appointed persons before performing functions under the banking laws (Bank of Ghana, 2016b, p. 115).

Preliminary matters include Sections 1 through 3 and the related sub-sections of Act 930 of 2016.These Sections and their sub-sections discuss applications of Act 930 of 2016, Act 179 of the Companies Act of 1963;and the supervisory and regulatory role of the Bank of Ghana in all matters relating to deposit-taking business, among others. Licensing of banks and specialised deposit-taking institutions is discussed in Sections 4 through 24 and their related sub-sections. Enactments in these Sections and their sub-sections include who qualifies to engage in a deposit-taking business, and deposit-taking microfinance institution; the exclusive right of the Bank of Ghana to issue licenses to deposit-taking institutions; requirements and application for the issuance of a deposit-taking business licence; types and prerequisites for issuance of banking and specialised deposit-taking licenses; conditions under which the bank of Ghana would issue a provisional licence to the subsidiary of a foreign bank or specialised deposit-taking institution; the right of the Bank of Ghana to vary the conditions for a rural or community bank or any other specialised deposit-taking institution; the right of a specialised deposit-taking institution to invite the general public to subscribe to its shares only upon receipt of final approval from the Bank of Ghana, the latter's right to vary the foregoing condition for rural and community banks, and the imposition of an administrative penalty for violation of the foregoing condition; conditions under which the Bank Ghana would finally approve and issue a banking or specialised deposit-taking licence to an institution; non-transferability or assignment of a banking or specialised deposit-taking licence and conditions for issuance of same; conditions for refusal and revocation of a licence; establishment of a central register and activities permissible by law to be engaged in by the licensed institutions such as acceptance of deposits, lending, financial leasing, electronic banking, and money transmission services, among other essentials; restrictions to banks, specialised deposit-taking institutions and financial holding companies on their direct engagement in activities related to commerce, agriculture or industry, and immovable property unless the immovable property is acquired for operational purposes, among other conditions; powers of the Bank of Ghana to close down, order repayment of monies, and impose penalty onan unauthorised banking or deposit-taking business; exclusive use of the word, bank, by institutions issued with a banking licence; need for institutions to display their licenses and ensure their places of transacting business are duly licensed by the Bank of Ghana; conditions for which representative offices could be established by a foreign bank in Ghana; the inability of a foreign specialised deposit-taking institution to establish a representative office in Ghana; and how a bank or specialised deposit-taking institution could make amendments to the company name, regulations or any other instrument under which it was originally established.

Capital and reserves of banks and specialised deposit-taking institutions are discussed in Sections 28 through 35 and their sub-sections. Essential financial information here includes minimum unimpaired paid-up capital to be prescribed by the Bank of Ghana; capital adequacy and other capital requirements of banks, specialised deposit-taking institutions and financial holding companies (herein referred to as financial institutions) relative to the risk and vulnerability of the Ghanaian financial system; conditions for which capital adequacy may be presented on a consolidated basis; request for additional capital to mitigate concentration of risks in the licensed financial institution; licensed financial institution's prompt notification of the Bank of Ghana of non-compliance with minimum capital adequacy ratio and provision of particulars on same; penalty for non-compliance with capital requirements; establishment and maintenance of a reserve fund by a licensed financial institution; and restrictions on declaration and payment of dividends to shareholders.

Sections 36 through 41 and their related sub-sections of Act 930 outline enactments on liquidity of banks, specialised deposit-taking institutions, and financial holding companies licensed in Ghana. Specifically, these Sections and sub-sections address liquidity requirements; conditions under which the liquid assets of a financial institution would be maintained on a consolidated basis; additional liquidity requirements for the assumption of additional risk; notification of Bank of Ghana of non-compliance with minimum liquidity requirements; penalties for non-compliance with liquidity requirements; and maintenance of a net open position based on the directive of the Bank of Ghana.

The issue of ownership and control in financial institutions is addressed in Sections 42 through 60 of Act 930 . Enactments in these Sections and sub-sections affirm the need for a financial institution to submit to the Bank of Ghana, at least twice a year, a complete organisational structure of the corporate group to which it belongs to ease supervision on a consolidated basis; requirements and application for registration as a financial holding company;display of a copy of certificate of registration at the head office of a financial holding company; restrictions on activities of financial holding 
companies; power of the Bank of Ghana to require restructuring of ownership of a financial institution; conditions for which the registration of a financial holding company may be withdrawn by the Bank of Ghana; submission of information on significant shareholding to the Bank of Ghana at the end of June and December of each year; conditions under which the Bank of Ghana may disapprove a transfer of shares in a financial institution; cap or restriction on ownership; conditions for which a financial institution may engage in sale, merger, amalgamation, and reconstruction of its businesses; consideration and review of application for approval for a financial institution to engage in sale, merger, amalgamation, and reconstruction of its businesses; penalties for non-compliance; right of the Bank of Ghana to prescribe rules on corporate governance for a financial institution to assure prudent management and operations; duty of directors to report to the Bank of Ghana on the financial institution's inability to continue business as a going concern; conditions for nonqualification as director and key management personnel of a licensed financial institution; disclosure of interest by persons aspiring to the positions of director and key management personnel; and the right of the Bank of Ghana to intervene in the appointment of chief executive officers and their deputies in financial institutions.

Restrictions on lending and investment by banks, deposit-taking institutions and financial holding companies form the basis for discussion in Sections 61 through 77 and their sub-sections. Enactment in these Sections includes prohibition of granting loan, advance or credit facility and guarantee against the security of a financial institution's shares; limits on financial exposure, including aggregate liability of secured financial exposure not exceeding twenty-five percent (or a lower percentage to be determined or prescribed by the Bank of Ghana) of net own funds of the financial institution; the need for unsecured financial exposure not to exceed ten percent of net own funds of the financial institution; the need for consolidation of financial exposure limits by licensed financial institutions; restrictions on transactions with an affiliate; restrictions on transfer or purchase of low quality or non-performing assets from affiliates, associates, shareholders, directors, key management personnel, related person, group of related persons or their related interest without the written approval of the Bank of Ghana; restrictions on inter-institutional placements and loan receipt or deposit in the country by a financial institution with less than required level of capital adequacy ratio without the written approval of the Bank of Ghana; restrictions on financial exposures to an insider; limits on financial exposures to related parties on a consolidated basis; restrictions on lending to staff; essential requirements for lending to insiders and their related interests; limitations to the establishment of subsidiary companies by banks and specialised deposit-taking institutions; restrictions on investment in non-subsidiary companies by banks and specialised deposit-taking institutions; report on the particulars of a large exposure to the Bank of Ghana; implementation and maintenance of a proper policy on assets classification, provisioning for bad debts and write-offs; limits on a foreign exchange business; and powers of the Bank of Ghana to impose stricter prudential limits for a period it considers appropriate.

Laws regulating accounts and audit of financial statements of financial institutions form the basis for discussion in Sections 78 through 90 and their sub-sections of Act 930. Enactments here include the need for financial institutions to prepare and present their financial accounts and statements in line with internationally accepted standards; and based on standards or rules outlined in the Basel Core Principles and approved by the Bank of Ghana; prepare and keep accurate accounting records for a period not less than ten years; and present solo and consolidated financial statements at the end of each calendar year. Others include appointment of auditors by financial institutions and ultimate approval by the Bank of Ghana; condition for which the Bank of Ghana may appoint auditors for a financial institution; right of an auditor to the information of a financial institution; submission of a report by the auditor to the financial institution and Bank of Ghana; periodic meetings among the Bank of Ghana, financial institutions and their auditors to discuss matters relevant to banking supervision; duties of an auditor to report any potential insolvency to the Bank of Ghana; request for special audit and additional information by the Bank of Ghana; conditions under which the Bank of Ghana would request for the termination of an auditor's appointment by a financial institution; and conspicuous display of copies most recent audited financial statements in all branches of licensed financial institutions.

Powers of the Bank of Ghana to regulate, supervise, and issue directives to licensed financial institutions are stated in Sections 91 through 106 and the related sub-sections of Act 930. Other considerations in these sections are request by the Bank of Ghana for information and periodic returns for supervision purposes; right of the Bank of Ghana to examine, investigate or scrutinise the operations and affairs of a licensed financial institution; power of access to and verification of information as well as custody of records required by Bank of Ghana's appointed examiners; submission of a copy of examined report to the affected financial institution, and requesting same to provide, within forty-five days, a written explanation on findings contained in the examination report, steps taken to address the challenges, and specific time periods; Bank of Ghana's follow-up action on examination and other supervisory reports; condition for the appointment of an advisor to the management team of a financial institution; remedial measures to be prescribed for a financial institution and its directors and key management personnel for non-compliance to recommendations for the findings from the examination; non-declaration and distribution of dividends by adequately capitalised financial institutions with significant losses; and submission of a capital restoration plan to the Bank of Ghana by undercapitalised and significantly undercapitalised financial institutions, among other measures.

Enactments related to official administration of financial institutions are presented in Sections 107 through 122 and their accompanying sub-sections of Act 930. Acts in these sections outline the basis for which the Bank of Ghana would appoint an official administrator for a bank or specialised deposit-taking institution, and the duration of the appointment; vesting of powers, functions, and responsibilities of shareholders, directors, or key management personnel of a bank or specialised deposit-taking institution in the official administrator; oversight responsibility of the Bank of Ghana on the official administrator; immediate suspension of dividend and other forms of capital distribution to shareholders by the official administrator; Bank of Ghana's imposition of moratorium to suspend all or some payments by a bank or specialised deposit-taking institution in official administration; non-termination, non-acceleration or non- 
modification of a bank or specialised deposit-taking institution's existing contract with a third party when the former is in official administration; the control of properties, assets, books, and records of a bank or specialised deposit-taking institution by the official administrator upon his or her appointment; preparation and submission of inventory of assets and liabilities of the affected bank or specialised deposit-taking institution by the official administrator to the Bank of Ghana within ninety days of his or her appointment; steps to be taken by an official administrator to increase a financial institution's capital through existing shareholders, and recapitalisation through flotation of shares to new shareholders. With the approval of the Bank of Ghana, an official administrator may carry out merger or transfer in part, or in whole, the assets and liabilities of an affected bank or specialised deposit-taking institution, and approve the restructuring of liabilities of a bank or specialised deposit-taking institution; mandatory restructuring of a bank or specialised deposittaking institution by an official administrator without prior approval of affected creditors and shareholders; removal and replacement of directors and key management personnel by an official administrator with the approval of the Bank of Ghana; official administrator's immediate notification of the Bank of Ghana of illegal or fraudulent activities by significant shareholders, directors, key management personnel, attorneys, accountants or other professionals, and the initiation of civil action to claim damages and restitution against same; and remuneration and termination of an official administrator's appointment at the end of the specified period.

Steps for receivership and liquidation of banks and specialised deposit-taking institutions are stated in Sections 123 through 139 and their related sub-sections of Act 930. Enactments here include mandatory revocation of licence of a bank or specialised deposit-taking institution when either is found insolvent or likely to be insolvent in the next sixty days; initiation of receivership against the affected bank or specialised deposit-taking institution when the foregoing is established; prescription of qualifications and compensation for a receiver; notice and registration of receivership; oversight responsibility of the Bank of Ghana on the receiver; powers of the receiver as the sole legal representative of the affected bank or specialised deposit-taking institution; receiver's succession of rights and powers of shareholders, directors, and key management personnel of affected bank or specialised deposit-taking institution; effects of assumption of receivership including stay of legal proceedings, and suspension of the computation of interests and penalties against liabilities of an affected bank or specialised deposit-taking institution; suspension of the expiration term of a claim or right of the affected bank or specialised deposit-taking institution; unrestricted access to and control over the offices, accounting books, other records and assets of the affected bank or specialised deposit-taking institution by the receiver; receiver's taking of inventory of assets and use of liquidation values of the affected bank or specialised deposit-taking institution to establish a new financial position; setting aside of pre-receivership transactions such as gratuitous transfers to third parties executed within three years, and transactions with affiliates, insiders or key management personnel within five years prior to the receivership date; rights of the Bank of Ghana to determine claims; claims on eligible financial contracts and priorities in payment of claims; termination of receivership and presentation of final report to the Bank of Ghana; provisions on miscellaneous receivership and relationship with other enactments; and inability of a bank or specialised deposit-taking institution, despite Act 179 of the Companies Code of 1963, to engage in a voluntary winding-up without a written certification confirming same by the Bank of Ghana.

Miscellaneous provisions of Act 930 are contained in Sections 140 through 160 and their sub-sections. Provisions here include the right of an applicant to within thirty days, petition the Bank of Ghana for a review of an earlier decision on a licence application; right of an aggrieved financial institution to seek redress through arbitration as enshrined in Act 798 of the Alternative Dispute Resolution Act of 2010; review of Bank of Ghana's decisions through arbitration; conditions for release of unclaimed balances after two years of deposit or maturity; prohibition of floating charge; confidentiality obligations of officials and employees of the Bank of Ghana during and after their relationship with the latter, and penalties for contraventions thereof; secrecy of customer information, and agreements for information exchange; conditions for disclosure of information on a financial institution to the public by the Bank of Ghana, in spite of the confidentiality provision; obligation of the Bank of Ghana to not later than four months submit reports on trends and progress of deposittaking business in the country to the Finance Minister; protection from liability and indemnification of the AttorneyGeneral, officers of Bank of Ghana or any other person acting under the direction of the Bank of Ghana; nonindemnification of a person convicted of crimes arising out of activities covered in a law suit; collection of civil penalties by the Bank of Ghana; prosecution of offences and penalties by the Bank of Ghana through the Attorney-General; definition of key financial terms including the definitions of financial exposure and deposit-taking microfinance institution; repeal of the Banking Act of 2004, Act 673; and repeal of the Banking Amendment Act of 2007, Act 738. It concludes with a Schedule containing oath and declaration of confidentiality by office holders.

\subsection{Problem Statement}

Undoubtedly, the financial sub-sector is the mainstay of economies of advanced and developing nations including Ghana. In 2017, the total gross domestic product (GDP) of the world's economy was about US\$59.163 trillion. Ghana's GDP in 2017 was estimated at US $\$ 47.33$ billion, representing about $0.08 \%$ of the world's economy. Available data from Trading Economics (2018) indicate Ghana's average GDP from 1960 to 2017 was US\$10.85 billion. Ghana's respective GDP from 2008 to 2016 were: 2008 (US\$28.53 billion); 2009 (US\$25.98billion); 2010 (US\$32.17 billion); 2011 (39.57 billion); 2012 (41.94 billion); 2013 (47.81 billion); 2014 (39.89); 2015 (37.34); and 2016 (US\$42.8 billion).

Ghana's economy comprises three key sectors. These include the Agricultural, Industrial, and Services sectors. The financial sub-sector forms an integral part of the Services sector. The Services sector remains the largest contributor to Ghana's GDP in recent years; over the past ten years, the contribution of the Services sector to GDP has been phenomenal: 2008 (48.6\%); 2009 (49.2\%); 2010 (51.1\%); 2011 (49.1\%); 2012 (49.1\%); 2013 (49.8\%); 2014 (51.9\%); 2015 (54.6\%); 2016 (56.8\%); and 2017 (55.9\%). 
However, there has been a steady decline in growth rate of the Services sector from 2015 to 2017. For instance, while the Services sector growth rate in 2015 was 6.3\%, its respective growth rates for 2016 and 2017 were $5.7 \%$ and $4.7 \%$. The imminent question that begged for an answer is: "Could this be attributed largely to low contribution of the financial sub-sector whose performance is severely impacted by recent unfavourable developments in the banking subsector? Between August 2017 and August 2018, the Government of Ghana (GoG) expended over GHф4.7 billion on seven collapsed banks, namely United Trust (UT) Bank, Capital Bank, Beige Bank, Sovereign Bank, Construction Bank, The Royal Bank, and UniBank. In addition to the above, the Government of Ghana is expected to expend about GHф10 billion in order to meet the demands of depositors in the banking and other financial institutions.

The general business problem is failure of the Bank of Ghana (BoG) to ensure effective monitoring and supervision of activities and operations of institutions in the financial sub-sector to improve on their contribution to national development and growth. Though evidence of this phenomenon is prevalent in the Ghanaian setting, limited research has been conducted to unravel its socio-economic implications for the country.

The specific business problem is how the Bank of Ghana could mobilise the limited human capital at its disposal to enhance monitoring and supervision; and to ensure strict implementation of banking regulatory framework to affect, positively, national development and growth. The purpose of this research was to assess the effect of government's decision to sanitise the banking sub-sector on depositors' investments.

\subsection{Research Objectives}

\subsubsection{General Objective}

The main purpose of this research was to examine the implications of the banking sub-sector reforms for key stakeholders such as depositors, and the relative effect on their funds.

\subsubsection{Specific Objectives}

Specifically, the present research sought to achieve the ensuing objectives:

- Examine the corporate governance approach of the affected local banks

- Assess the capital levels and solvency of the affected indigenous banks

- Evaluate the effect of affected banks and specialised deposit-taking institutions on the safety of depositors' funds

- Make recommendations for regulatory reforms to enhance stability of the Ghanaian banking system

\section{Literature Review}

This section presents a review of existing works relevant to the study. It begins with a brief theoretical framework and concludes with thematic discussions on scientific studies essential to the current research. Some of the themes discussed in this section include financial health of banking institutions, corporate governance in the banking sub-sector, investor risk tolerance level, and merger and acquisition (M\&A).

\subsection{Theoretical Framework}

The Capital Asset Pricing Model (CAPM) developed by Sharpe (1964) was adapted and used in the current research. The CAPM helps investors to make informed choices on investment portfolios, calculate the prices of securities in the capital market, and to measure the value of risky assets during mergers and acquisitions (M\&As).

Sharpe (1964) advanced a series of assumptions to lend credence to CAPM. Among these include an investor's ability to earn higher returns should he or she decide to assume additional risk; the outcome of any investment is viewed by the investor in probabilistic terms. That is, the outcomes are perceived in a probability distribution; the expected risk and rate of return influence the eventual investment opportunity curve, and other investment opportunities available to the investor; the investor could decide to borrow limitlessly at the risk-free rate, and hold a long position (pp. 427-431). The following equation underlies Sharpe's (1964) assumptions:

$\mathrm{U}=\mathrm{f}(\mathrm{Ew}, \mathrm{Sw})$

Where:

$\mathrm{U}=$ Total utility

$\mathrm{f}=$ Function

$\mathrm{Ew}=$ Expected future wealth

$\mathrm{S} w=$ Predicted standard deviation of the possible divergence of actual future wealth from expected future wealth (p.428).

The application of Sharpe's (1964) assumptions to the current research implies investors in the banking subsector would channel their "limited" financial and other capital resources into productive use when allowed to operate freely without government "strict" regulations; de novo banks may be attracted to profit maximisation opportunities in the sub-sector. However, they would be prepared to assume additional risk; competition in the banking sub-sector would breed efficiency; and existing government regulations would stimulate banks to expand, and contribute positively to national economic development and growth.

The present study was premised on the following logic: if government is convinced that current practices among banks would lead to improve efficiency and creation of additional branches; attract new banks; create employment opportunities; contribute to national economic development and growth; and avoid exploitation of depositors, then she would take the necessary steps to relax some of her regulatory measures in the sub-sector. 


\subsection{Financial Health of Banking Institutions}

$\mathrm{Lu}$ and Whidbee (2013) examined the relative effects of variables such as the type of charter (licence), that is, state or national charter, measures of fragility in banking, and holding company structure on the possibility of bank failures, following the financial crisis in the late 2000s. The researchers employed logit regressions to identify the underlying causes of banks' failure in the 2000s; and to examine the contribution of bank-level characteristics, using economic and regulatory environment as a controlling variable.

Findings from the study revealed high failure rate among established banks with high non-performing loans, a debt portfolio dominated by mortgage or real estate loans, low capital ratios, excessive reliance on brokered deposits, relatively low liquidity, unimpressive or low capital ratio, and limited income diversity. The outcomes further revealed high failure rate among established banks with or without bailout. Financial fragility was found to have more devastating effect on newly established (de novo) banks and banks that witnessed expansion just prior to the crisis than on established banks.

The findings established an insignificant relationship between the likelihood of failure in newly established banks and the level of capital investment. This implies the level of capital investment was found not to have a strong effect on the possible failure of a de novo bank. However, findings from the present study contradicted this assertion; the research revealed the Bank of Ghana's decision to consolidate the five banks into one bank emanated from their financial inadequacies and the possibility of further capital deterioration in the foreseeable future. Variations in the research outcomes may be attributed to differences in geographic locations and jurisdictions; and the fact that strict adherence to banking regulatory measures may be more pronounced in the former research area than in the latter. Given the "recency" of banking institutional development in Ghana, the regulator in recent years, "relaxed" the implementation of certain regulations as a means to attract more investors into the sub-sector.

Abdullah (2015) sampled twenty-nine Bangladeshi banks and examined how liquid, profitable and solvent they are in the face of recent financial crisis in the country. The underlying objective was to provide investors with ample information to make firm and informed investment decision on the banking sub-sector of the Bangladeshi economy. The researcher adapted Altman's Z-Score to assess and predict the extent of failure among banks in the Bangladeshi economy. Financial data for the fiscal years 2009 through 2014 were gathered and used in the study. Outcomes from the study showed the equity market and banking industry in Bangladesh are still at the developing stage when benchmarked to international standards. Bangladesh remains an emerging capital market. However, when subjected to intra-analysis, one observes a considerable improvement in the banking sub-sector relative to the equity market.

Further, the research findings revealed twenty-two out of the twenty-nine sampled banks were insolvent during the fiscal years under review; only seven banks exhibited traits of financial solvency. Abdullah (2015) notes trend analysis and key financial ratios play an influential role in the investment decisions of investors in the financial sub-sector. Thus, the research outcomes would guide potential investors in the choice of banking institutions as appropriate investment destination in the Bangladeshi economy. Findings from Abdullah's (2015) study serve as a proto type to the current research; the outcomes would help investors identify and assess the relative strength of the sampled banks, appreciate the efforts of government in stemming the tide of the financial challenges; and to make an informed investment decision.

\subsection{Corporate Governance in the Banking Sub-Sector}

Mulbert (as cited in Ashley, 2013) assessed the relationship between poor corporate governance practices and the financial crisis recorded in 2006 through 2008; and the devastating impact of the financial turmoil on economies across the globe. The author assessed how the development of good corporate governance in the banking sub-sector could permeate all other sectors of a given economy. Stated differently, the purpose of Mulbert's (as cited in Ashley, 2013) study was to determine how the identification and formulation of meaningful corporate governance policies for financial institutions could have a positive effect on various industries. The author relied extensively on existing literature to explain variations in the use of the term corporate governance; and to theoretically analyse the mechanisms of corporate governance of banks with reference to their major stakeholders such as stockholders, depositors, and bondholders. The author utilised the principal-agent concept to determine the difference between corporate governance of regular companies and financial institutions. The study focused on the principal-agent problems in banks and how those problems weaken the smooth performance of the banking sub-sector.

The research outcomes attributed the financial crisis witnessed in 2006 through 2008 to the failure in banks' corporate practices. The findings suggested the need for banks to institute measures that would ensure significant improvement in their risk management techniques; there is the need for bank executives to review and raise objections when necessary, to the board's proposals than to accept them "en bloc" for implementation.

Findings from the study revealed non-executive directors (NEDs) of financial institutions are expected to demonstrate knowledge, actively participate in activities organised by the board, and to be committed to higher standards. The banks are also expected to ensure active participation of the Financial Services Authority (FSA) in their scheme of activities.

The research outcomes showed bank's corporate governance strategy differs from that of a regular company in that the former implements prudential regulation and deposit insurance. The complexity of the bank's corporate governance policy and its attendant problems do not permit its adaptation as a catalyst for governing generic companies.

\subsection{Investor Risk Tolerance Level}

Santacruz (as cited in Ashley, 2013) extended the existing works on risk tolerance by examining the relationship between general economic conditions and risk tolerance of investors. Specifically, he assessed the extent to which 
investors' risk tolerance is influenced by general economic conditions. To facilitate the collection and analysis of the research data, the investigator adopted the Risk Tolerance Scores (RTS) instrument developed by FinaMetrica, a riskprofiling firm located in Australia, and the Consumer Sentiment Index (CSI) expounded by the Westpac-Melbourne Institute. The RTS measures the risk tolerance level of consumers whereas the CSI focuses on the economic condition of consumers in general. The Risk Tolerance Index was measured on a scale of 0 to 100 , depending on participants' answers for twenty-five behavioural questions bordering on investments. A lower score connotes a lower risk tolerance, vice versa.

The inquirer measured the consistency and effectiveness of the CSI instrument against the Roy Morgan Consumer Confidence Rating instrument, and the University of Michigan Consumer Sentiment Index instrument, and found a correlation among the instruments' results. Findings emanating from the study suggested there is no relationship between general economic condition and investor risk tolerance. They also revealed the absence of relationship between consumer sentiment index and risk tolerance index; and confirmed the non-existence of a relationship between performance of the stock market and risk tolerance index.

The researcher employed data collected from the Risk Tolerance Scores Survey (RTSS) and the Consumer Sentiment Index Survey (CSIS). While participants in the CSIS were selected using the random sampling technique, the RTSS drew heavily on the purposive sampling technique. To ensure the effectiveness of the RTS instrument in the research process, and to validate the research findings, the inquirer controlled for the Risk Tolerance Scores using respondents' demographic variables such as marital status, income, age, gender, net worth, number of dependents, and level of education. The research outcome is replicable; it extends the body of existing knowledge in the research area. The recency of the research data (1998 - 2007) further enhances the reliability of the findings.

\subsection{Mergers and Acquisitions (M\&As)}

Nicholas and Forsythe (as cited in Ashley, 2013) presented a synopsis of the revised version of Statement of Financial Accounting Standards (SFAS) No. 141, Business Combinations. The revised version, Statement of Financial Accounting Standards (SFAS) No.141(R) brings along novel guidelines for determining values of assets and liabilities in mergers and acquisitions, and other changes in control activities. The underlying objective was to assess the extent to which the introduction of SFAS 141(R) impacts the valuation and accounting for mergers and acquisitions (M\&As) compared with SFAS No. 141 in areas such as step acquisitions, measurement date for equity securities that are issued in combinations, in-process research and development (IPR\&D), acquisition-related cost of the acquirer, initial recognition of contingent assets and liabilities, and recognition of contingent considerations at acquisition date and subsequent periods, among others.

Findings from the research indicated SFAS No. 141(R) would compel companies to disclose more details, and to be transparent in their bidding activities. This would ensure significant improvement in financial reporting standards. SFAS No. 141(R) emphasises, strongly, on the measurement of assets and liabilities using fair or market value; it is the first to significantly integrate a standard of the Financial Accounting Standards Board (FASB) with the International Accounting Standards Board (IASB). Most of the valuation and accounting requirements in SFAS No. 141(R) bridge the gap between Generally Accepted Accounting Principles (GAAP) and International Financial Reporting Standards (IFRS). This enhances the efforts aimed at emerging with a common and universal accounting standard for all countries across the globe.

The study outcomes revealed the significance of SFAS No. 141(R) in contemporary accounting for assets, liabilities, and stocks in mergers and acquisitions. It affords bidding and acquired firms the opportunity to be abreast of new measures that are acceptable in the valuation and accounting for items in the acquisition process. Among many of the changes is the accounting for in-process research and development (IPR\&D) in mergers and acquisitions. Under SFAS No. 141, the cost of IPR\&D is included in the acquisition and written off immediately whereas SFAS 141(R) emphasises on the recognition of IPR\&D as an intangible asset, but distinct from goodwill; the recognition is made at the purchase date, and it is not written off immediately.

Kalpic (2008) assessed the extent to which mergers and acquisitions result in sustainable competitive edge and improved financial performance for the combining firms. The study aimed at assessing the impact of mergers and acquisitions on the maximisation of shareholders' wealth. It sought to investigate the effect of huge takeovers on the performance and survival of smaller firms in the industry. The study was framed on two significant theories, the "Merger and Industry Consolidation Theory" by Deans, Kroeger, and Zeisal (2003) and the "Rule of Three Theory" by Sheth and Sisodia (2002). The former underscores the significance of scale and growth in maintaining the concentration process of the industry while the latter makes a prediction on the dominance of the industry by only three "players" at the final stages of the merger and acquisition process. The author discussed the merger and industry consolidation theory and the rule of three-theory in the light of growing merger and acquisition trends, and the impact of rapid technological transformation and advancement on the concentration of industries at the local, regional, and global levels. Statistical figures (in a histogram) from the work of Vizjak (2008) were presented to demonstrate the chronological occurrence of merger and acquisition events from 1982 through 2007. The author discussed the logical reasons that are paramount to the strategic positioning of firms in the fast-growing and dynamic business settings.

Contrary to the claim and prediction of the merger and industry concentration theory, the research findings showed lack of strong support for industries' ability to fully benefit from the concentration process and economies of scale; industries that were perceived to be highly concentrated several years ago are less concentrated today. Notable among these are the automobile industry which was more concentrated in the 1960s than it is today, and the oil industry which was more concentrated about fifty-five years ago than it is today. The findings indicated management's understanding of the concentration process at the local, regional, and global levels is very monumental to its ability to formulate strategies that would propel its organisation to greater economic and financial heights. Companies that operate 
at the international level have fewer problems with economies of scale, they are rather exposed to the dangers of diseconomies of scale, and they have to contend with the growing problems emanating from variations in regulations, legal and fiscal systems pertaining to the markets in various countries.

The study elicited some of the key ways in which management could strategically emerge with decisions that would be useful to merger and acquisitions, and to industry concentration. The study affirmed the firm's ability to develop, grow, and dominate in the industry transcends takeovers; management has to consider other bottlenecks such as distance cost (proximity to the target market) in the decision making process. These considerations enhance the economic usefulness of takeovers to the firm.

\section{Research Methodology}

The quantitative approach to scientific inquiry formed the basis for the conduct of this research. A cross-sectional design, an example of survey design, was adapted and used in the study. This allowed the researcher to gather relevant research data over a specific period of time (Ashley, Takyi \& Obeng, 2016; Creswell, 2009; Frankfort-Nachmias and Nachmias, 2008). Data required for the research were obtained essentially from secondary sources. These included text books, journals, research papers, newspaper publications; electronic databases of the Bank of Ghana, Google Search Engine, Index Mundi, financial websites such as Tradingeconomics.com, among others. Financial data of selected banking institutions were collected and used in the research.

\subsection{Units of Analysis}

The units of analysis in the current research included the United Trust (UT) Bank, Capital Bank, UniBank, Royal Bank, Beige Bank, Sovereign Bank, and Construction Bank. Thus, the units of analysis comprised the two banks that were acquired by GCB Bank in August 2017; and the five banks that were consolidated into one bank in August 2018. The collapse of the five banks led to the establishment of the Consolidated Bank Ghana Limited by the Government of Ghana on the foregoing date.

\subsection{Analytical Tools}

Descriptive statistics and regression models were used to describe the research variables; and to evaluate their behaviour over the stated time frame in the Ghanaian banking sub-sector. Measures such as the range and standard deviation were employed to describe the extent of dispersion about the central tendency (Ashley, Takyi \& Obeng, 2016; Creswell, 2009; Frankfort-Nachmias \& Nachmias, 2008). Regression statistics were generated to explain the R square, Adjusted R square, and Standard error values, among others.

\subsection{Research Variables}

The independent research variable included banks and specialised deposit-taking institutions that are in distress and failing while the dependent research variable was the relative effect ofthese distressed and failing banks and specialised deposit-taking institutions on the safety of depositors' funds.

\subsection{Regression Model}

The one-way analysis of variance (ANOVA) was adapted to measure the effect and level of interaction of affected banks and specialised deposit-taking institutions on the safety of customers' deposits. The Microsoft Excel analytical software was used in the research. Diagrams and tables were derived from Microsoft Excel to explain the research data. The ANOVA is given by the formula:

$\mathrm{F}=$ MSbetween $/$ MSwithin, in which

MSbetween =SSbetween $/$ dfbetween;

MSwithin =SSwithin $/$ dfwithin

Where:

$\mathrm{MS}=$ Mean squared

$\mathrm{SS}=$ Sum of squares

The degrees of freedom (df) under the ANOVA is computed as follows:

degrees of freedom (total) $=\mathrm{n}-1$

degrees of freedom (between) $=\mathrm{k}-1$

degrees of freedom (within) $=\mathrm{n}-\mathrm{k}$

Where:

$\mathrm{n}=$ Sample size

$\mathrm{k}=$ Number of groups or levels

\subsection{Research Hypotheses}

The study tested the causal relationship between banks and specialised deposit-taking institutions that are in distress and failing, and the safety of customers' deposits using the following null and research or alternative hypotheses: Ho: $\mu 1=\mu 2$; this implies affected banks and specialised deposit-taking institutions have no strong negative effect on the safety of depositors' funds.

H1: $\mu 1 \neq \mu 2$; this implies affected banks and specialised deposit-taking institutions have a strong negative influence on the safety of depositors' funds. 


\section{Research Findings and Discussions}

Most banks licensed in Ghana operate a number of branch networks. The number of branch networks depicts the level of operational expansion undertaken by each bank. Data in Figure 1 indicate the number of branch networks operated by each of the five affected banks as at the consolidation date. The study revealed the following respective branch networks for the implied banks: UniBank 54, Royal Bank 14, Beige Bank 14, Sovereign Bank 3, and Construction Bank 1. UniBank operated 54 branch networks in nine regions across the country. Figure 1 reveals the total number of branch networks operated by the five defunct banks as 86 while GCB Bank operates 183 branches across the country. In percentage terms, the total number of branch networks of the five collapsed banks (86) represents only about $47 \%$ $((86 \div 183) \times 100 \%=0.4699 \times 100 \%=47 \%)$ of the total GCB Bank branches $(183)$.

Available records indicate UniBank maintained 878 regular staff and 990 outsourced staff. This implies the total number of employees at UniBank was about 1,778 $(878+990=1,778)$. However, the total number of employees at GCB Bank is 1,915. Comparatively, the total number of employees at UniBank, both regular and outsourced $(1,778)$ represented about $92.85 \%((1,778 \div 1,915) \times 100 \%=0.9285 \times 100 \%=92.85 \%)$ of the total employees at GCB Bank $(1,915)$. The total number of branch networks operated by UniBank (54 branch networks) represented only about $29.51 \%((54 \div 183) \mathrm{x}$ $100 \%=0.2951 \times 100 \%=29.51 \%$ ) of GCB Bank branches (183) nationwide.

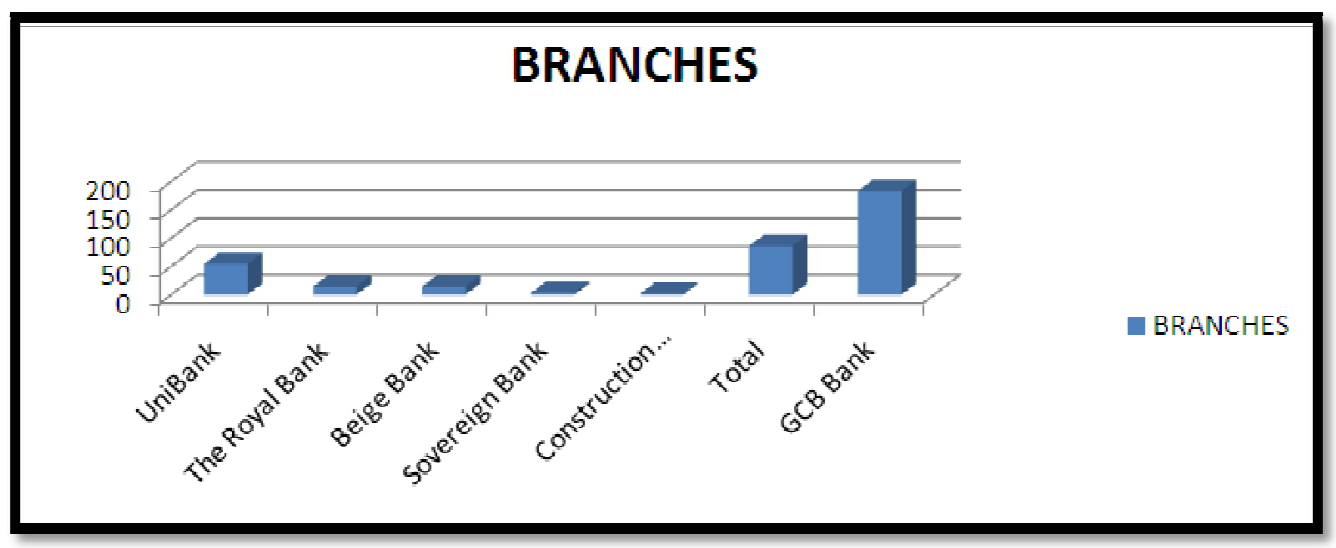

Figure 1: Five Banks' Branches Relative to Gcb Bank Branches

On the average, UniBank maintained about 33 staff per branch $(1,778$ employees $\div 54$ branch networks $=$ 32.9259); this was about three times the average number of staff (11 staff per branch network) at GCB Bank $(1,915$ employees $\div 183$ branch networks $=10.4645$ ).

\begin{tabular}{|c|c|}
\hline \multicolumn{2}{|c|}{ Descriptive Statistics } \\
\hline Mean & 17.2 \\
\hline Standard Error & 9.58853482 \\
\hline Median & 14 \\
\hline Mode & 14 \\
\hline Standard Deviation & 21.44061566 \\
\hline Sample Variance & 459.7 \\
\hline Kurtosis & 3.49720517 \\
\hline Skewness & 1.803241411 \\
\hline Range & 53 \\
\hline Minimum & 1 \\
\hline Maximum & 54 \\
\hline Sum & 86 \\
\hline Count & 5 \\
\hline
\end{tabular}

Table 1: Descriptive Statistics on Banks' Branches

A statistical description of the number of branch networks operated by Beige Bank, Sovereign Bank, Construction Bank, Royal Bank, and UniBank is presented in Table 1. The output in Table 1 shows respective Kurtosis and standard error values of 3.497 and 9.589. The standard error value indicates the extent to which the coefficients are significantly different from zero. The skewness of the distribution is 1.803 while the sample variance is 459.7. Each of the five consolidated banks had varied financial challenges in terms of liquidity support, capital deficit, capital adequacy ratio, minimum capital requirement, and non-performing loans, among others. For instance, as of May 2018, Sovereign Bank and UniBank had received a respective liquidity support of $\mathrm{GH} \$ 12$ million and $\mathrm{GH} \$ 3.25$ billion from the Bank of Ghana while as at August 2017, UT Bank and Capital Bank had received the following respective liquidity support from the Bank of Ghana: GH\$860 million and GHф610 million. 


\subsection{Key Performance Indicators}

\subsubsection{Capital Adequacy Ratio}

Section 29 (1) of the Banks and Specialised Deposit-Taking Institutions Act of 2016, Act 930, hereinafter referred to as Act 930, affirms the Statutory powers of the Bank of Ghana to "prescribe a risk-based capital adequacy requirement, which may be measured as a percentage of the capital of the bank, specialised deposit-taking institution or financial holding company to its assets" (Bank of Ghana, 2016b, p. 28). Further, sub-section 2 of Section 29 of Act 930 states the minimum capital adequacy ratio shall be at least 10\%. Findings from the current research revealed the respective capital adequacy ratio of Sovereign Bank, Beige Bank, and UniBank as at the consolidation date was: $-11 \%$; $-17.18 \%$; and $-74.65 \%$. As at the consolidation date, Bank of Ghana's minimum capital requirement for each licensed bank was GHф120 million; and the capital adequacy ratio in monetary terms was GH\$12 million (GHф120 million x $0.10=\mathrm{GH} \phi 12$ million).

The foregoing implies,to restore Beige Bank’s capital adequacy ratio,one would have required about GH\$32.62 million $((\mathrm{GH} \phi 12$ million + $(\mathrm{GH} \phi 12$ million $x$ 0.11) + GHф12 million $=\mathrm{GH} \phi 20.616$ million $+\mathrm{GH} \phi 12$ million $=\mathrm{GH} \$ 32.616$ million). Similarly, restoring the respective capital adequacy ratio of Sovereign Bank and UniBank would have required GH\$25.2 million and GH\$101.58 million respectively. Evidently, the capital adequacy ratios maintained by the Sovereign Bank, Beige Bank, and UniBank as at the consolidation date were in violation of Section 29, sub-sections 1 and 2 of Act 930.

\subsubsection{Non-Performing Loans}

One of the major setbacks to the efficient and effective operation of banks is high non-performing loans. Prior to their acquisition by GCB Bank, UT Bank and Capital Bank had respective non-performing loans of GH\$438 million and GH\$333.88 million. In addition, UT Bank recorded non-performing loans of US\$20.7 million. As at June 2018, the total nonperforming loans amount in Ghana's financial sub-sector was estimated at GHф8 billion. This was in excess of the GH\$6.2 billion recorded in 2017. Beige Bank's non-performing loans were equivalent to $72.80 \%$ while the financial records of the Royal Bank showed non-performing loans of about 78.80\%. The financial records of UniBank depicted non-performing loans of about 89\%. This implies about GH\$3.33 billion (GH\$3.74 billion x $0.89=\mathrm{GH} \$ 3.3286$ billion) of the GH\$3.74 billion extended by UniBank to customers in the form of loans and advances was categorised as non-performing. High nonperforming loans rates are a recipe for financial disaster; they cripple the liquid base of the implied banking institution; and make refunds to depositors quite difficult. The relatively high non-performing rates recorded by UniBank, Royal Bank, and Beige Bank might have accounted strongly for their operational challenges and eventual liquidation and consolidation.

Total loans advanced by UniBank to its shareholders, related, and connected parties amounted to about GH $\$ 5.3$ billion (GH\$3.7 billion + GHф1.6 billion = GHф5.3 billion), representing about 75\% ((GH $\$ 5.3$ billion $\div$ GH $\$ 7.066$ billion) $\mathrm{x}$ $100 \%=0.7501 \times 100 \%=75.01 \%$ ) of the bank's estimated total assets value (GH 47.066 billion). This was in excess of Bank of Ghana's approved threshold of 25\% as stated in Section 42 (1) of Act 673; and Section 62 (1) of Act 930. This impacted adversely on the bank's financial base as it had challenges refunding customers' deposits on demand.

\subsubsection{Corporate Governance and Risk Management}

One of the significant challenges to the successful operation of banks in the Ghanaian economy is poor corporate governance. The research findings revealed UniBank had good corporate governance and operating framework. However, the Board and Management of UniBank seldom applied the established framework to their key and strategic management and investment decisions. This corroboratesMulbert (as cited in Ashley, 2013) who found a strong link between failure in banks' corporate practices and the financial crisis witnessed in 2006 through 2008. Lack of effective implementable corporate governance framework was a challenge to almost all the other affected banks namely Sovereign Bank, Beige Bank, Royal Bank, and Construction Bank. Non-compliance was identified as a major contributory factor to the unprofitable run of UniBank.

The success of financial institutions, including banks, is nucleated around the existence of an effective operational risk management strategy. In most cases, banks lay premium on sound investment strategy to the neglect of operational risk management. However, an effective operational risk management strategy creates room for a successful investment decision. The findings revealed most of the affected banks dwelt more on investment strategy than on operational risk management. The research outcomes showed formal risk management framework was non-existent at UniBank.

\subsubsection{Submission and Display of Audited Financial Statements}

Section 81 of Act 673 of the Banking Act of 2004, and Section 90 (1) and (2) of Act 930 of the Banks and Specialised Deposit-Taking Institutions Act of 2016 require each licensed bank to display copies of its audited annual financial statements in a conspicuous place in each of its branches; and to submit a copy of same to the Bank of Ghana not later than three months after the end of its financial year. Findings from the research revealed a clear violation of this provision for two consecutive years by UniBank; the bank failed to present its audited financial statements and denied its depositors and the general public access to these important financial documents during the years, 2016 and 2017. Generally, potential investors rely on financial records to examine certain key performance indicators; and to make informed investment decisions. The absence of this financial information to the public might have affected UniBank's ability to attract new investors, both local and foreign, to inject fresh capital into its operations to salvage the bank from total collapse. 


\subsubsection{Revocation of Licence}

Section 48 (1) (d) of Act 930 permits the Bank of Ghana to withdraw the licence of a bank when the former determines the latter was issued with a licence based on false or inaccurate information. The research findings revealed Beige, Sovereign, and Construction banks obtained their operating banking licenses by false pretences; the stated capital of most of these banks could not be accessed for day-to-day operations. For instance, GH\$80 million of the GH\$120 million initial paid-up capital of the Construction Bank was said to have been deposited with the National Investment Bank (NIB) and UniBank. However, the outstanding initial paid-up capital (GH\$80 million) could not be traced to these banks. At the final approval stage of Capital Bank's application, shareholders produced placement certificates issued in their individual names by financial institutions instead of presenting an escrow account. Besides, no new funds were transferred to Capital Bank beyond the initial investment capital of GHф23.3 million, representing about 38.83\% of the total minimum capital requirement of $\mathrm{GH} \phi 60$ million.

Routinely, the Bank of Ghana embarks on a quality assets review (QAR) or stress test to assess the relative operational strength and solvency of banks licensed in the country. A similar exercise undertaken by the Bank of Ghana in 2016 revealed UniBank and Royal Bank were significantly under-capitalised. Bank of Ghana's 2014 examination report on Capital Bank noted 24 infractions in the management and operations of Capital Bank. The 2015 examination report revealed only 4 of the 24 infractions noted in 2014had been resolved. The foregoing implies Bank of Ghana's decision to revoke the licenses of the seven affected banks could not be described as a "deliberate witch-hunt," it was in consonance with prescribed rules and regulations in Act 930.

\subsection{Distressed and Failing Banks and Deposit-Taking}

\subsubsection{Institutions}

As stated earlier, the financial sub-sector forms the nucleus of developed and developing economies, including Ghana. Therefore, it is imperative for it to be strengthened to assure its enormous contribution to the nation's socioeconomic development and growth. The outputs in Figures 3 and 4 depict the estimated costs to be incurred by the Government of Ghana to resolve and clean up the banking sub-sector; the figures depict the various banks and specialised deposit-taking institutions' outstanding commitments to depositors.

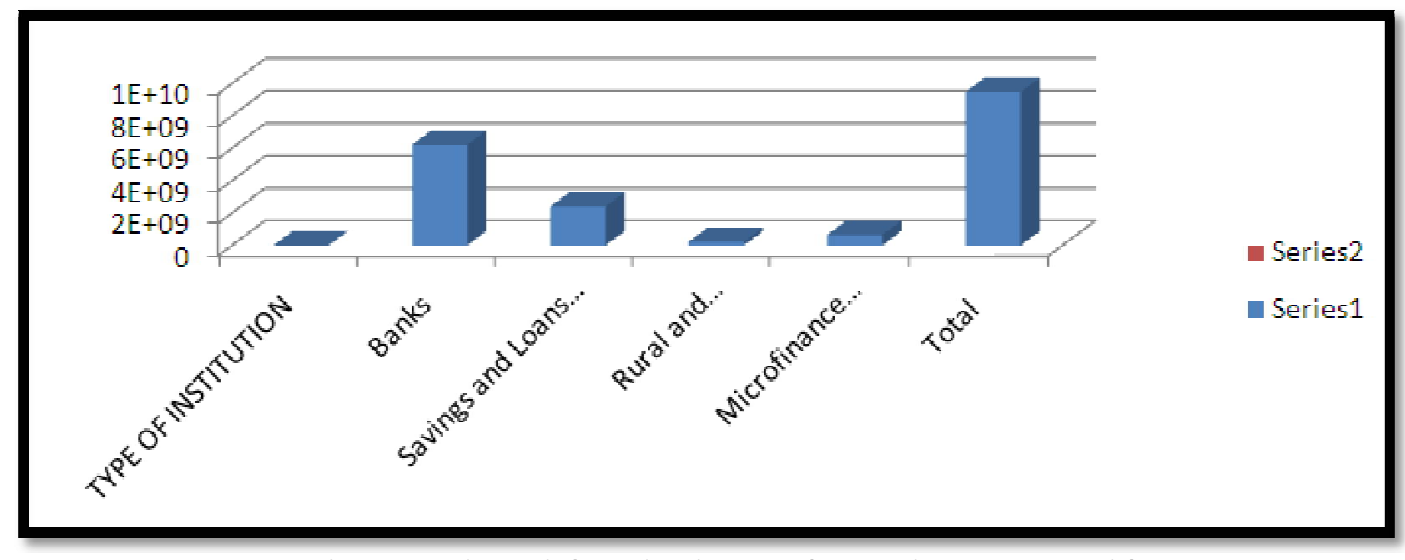

Figure 2: Financial Institutions and Deposits to Be Repaid

Available statistics show a total of about GHф10 billion is required to pay off the deposits of customers in selected banks and specialised deposit-taking institutions that are already distressed; and those that are failing. Activities in the financial sub-sector are dominated by banks and specialised deposit-taking institutions; the contribution of banks and specialised deposit-taking institutions to the pool of resources in the financial sub-sector is very high. Conversely, banks and specialised deposit-taking institutions contribute painstakingly to the challenges saddled with the Ghanaian financial sub-sector. Data in Figure 2indicate nine distressed and failing banks had the highest commitment (GHф6.2 billion) to depositors. This represents $62 \%$ of total commitments to depositors. Twenty-one Savings and Loans Companies were found to be in distress and failing. The total commitment of these twenty-one savings and loans companies to their depositors was estimated at GH $\$ 2.4$ billion, representing $24 \%$ of total commitments to depositors. The commitments of banks and savings and loans companies to their respective depositors were determined based on the gap estimated to exist between total deposits and good assets available to support payouts and deposit transfers.

The research findings revealed thirty-one Rural and Community Banks are in distress and failing; the financial commitment of these banks to their depositors amounts to GH\$220,741,856. The estimated amount to be paid to each depositor is $\mathrm{GH} \phi 1,250$. Some Microfinance institutions are equally saddled with financial challenges. In all, three hundred and nine Microfinance Companies were cited to be in distress and failing. The financial commitment of these institutions to their depositors is estimated at GH\$650 million; and each depositor is estimated to receive GHф1,250. The total estimated payouts to depositorsin all the financial institutions catalogued above amount to GH $\phi 9,470,741,856$; the difference of $\mathrm{GH} \phi 529,258,144$ is to be expended on miscellaneous costs of resolution.

In addition to the foregoing, the Government of Ghana would have to raise an estimated GH\$494 million (GH\&130 million + GH\$364 million = GH\$494 million) to assure adequate recapitalisation of banks such as the National Investment Bank (NIB) and Agricultural Development Bank (ADB) in which the State has equity stakes. Government of Ghana's equity 
stake in ADB is $32.30 \%$; she would have to invest additional GH\$130 million in order to meet the GH\$400 million minimum capital required by 31st December, 2018. An estimated GH\$364 million is required by the Government of Ghana to adequately capitalise NIB by 31st December, 2018.

\subsection{Ghana - Nigeria Key Comparisons}

The research findings revealed Ghana's banking sub-sector is saddled with challenges; some banks issued with tier 1 class 1 licence to operate as universal banks are financially struggling to remain solvent. Prior to the purchase and assumption of UT and Capital Banks by GCB Bank in August 2017; and subsequent amalgamation of UniBank, Beige, Sovereign, Construction and Royal Banks into a single bank called the Consolidated Bank Ghana Limited, Ghana had thirtyfive universal banks and four representative offices. In the light of the foregoing, a brief socio-economic comparison of certain key indicators of Ghana and Nigeria was conducted by the researcher to ascertain the "appropriateness" of the number (thirty-five) of universal banks licensed in Ghana relative to the number of universal banks licensed in Nigeria. The country, Nigeria, was selected randomly by the researcher. Table 1 presents useful data on the key socio-economic variables such as total land area and estimated population size. Data in the table indicate that geographically, Ghana and Nigeria occupy respective total land area of 23.9 million hectares and 92.38 million hectares. This implies the total land area of Nigeria is about 3.87 times (92.38 million hectares $\div 23.9$ million hectares $=3.8653$ ) the total land area of Ghana. All else held constant, the relatively wider geographical space presents Nigeria with more opportunity to explore and expand her financial market than Ghana.

\begin{tabular}{|c|}
\hline Ghana - Nigeria Key Comparisons \\
\hline Total Land Area \\
\hline Ghana 23.9 million hectares \\
\hline Nigeria 92.38 million hectares \\
\hline *Nigeria is about 3.87 times the size of Ghana \\
\hline ESTIMATED POPULATION \\
\hline Ghana 29.6 million \\
\hline Nigeria 195.9million \\
\hline *Nigeria is about 6.62 times Ghana's population \\
\hline GDP IN 2017 \\
\hline Ghana US\$46.56 billion \\
\hline Nigeria US\$376.3 billion \\
\hline *Nigeria's GDP in 2017 was about 8.08 times the GDP of Ghana \\
\hline LICENCED UNIVERSAL BANKS \\
\hline Ghana 35 (Plus 4 Representative Offices) \\
\hline Nigeria 25 \\
\hline Table 2: Ghana - Nigeria Key Socio-Economic Comparisons
\end{tabular}

Figures in Table2 affirm the respective estimated populations of Ghana and Nigeria as at August 2018 were 29.6 million and 195.9 million. This suggests Nigeria's population is about 6.62 times $(195.9$ million $\div 29.6$ million $=6.6182)$ Ghana's population. The significant difference in population sizes suggests, all things being equal, Nigeria's financial subsector has a comparative advantage over Ghana's financial sub-sector when it comes to the total number of depositors; and estimated volume and value of financial, specifically banking transactions. Ghana's gross domestic product (GDP) in 2017 was estimated at US $\$ 47.33$ billion while Nigeria's GDP in the same year amounted to US\$376.3 billion. Nigeria's GDP in 2017 was about 7.95 times (US\$376.3 billion $\div$ US $\$ 47.33$ billion $=7.9506$ ) Ghana's GDP in the same year. In spite of the "favourable" comparative analysis of the foregoing key socio-economic indicators, Nigeria has twenty-five universal banks; Ghana had thirty-five as at July 2017. Notwithstanding the relative decline in Nigeria's GDP from US\$405.1 billion in 2016 to US\$376.3 billion in 2017, she remains Africa's largest economy followed by South Africa (US\$349.3 billion) and Egypt (US\$237 billion) respectively.

Nigeria's socio-economic size and the number of licensed universal banks relative to Ghana affirm the need for the latter to strategically streamline the number of licensed universal banks to assure quality and not quantity. The need for strategic streamlining is cemented, further, by the uninspiring performance of some licensed universal banks in Ghana. The Bank of Ghana could encourage the establishment of additional bank branch networks, but cannot encourage the establishment of new banks without recourse to the following essentials: meeting the requirements for initial capital investments, constituting qualified board and management, and ensuring quality service delivery to depositors by licensed banks. 


\subsection{Results}

As stated in section 4.2, the research outcomes revealed a number of banks and specialised deposit-taking institutions that are in distress and failing; and the estimated cost of deposit funds required to meet their financial obligations to their depositors. These included nine banks (GH\$6.2 billion), twenty-one savings and loans companies (GHф2.4 billion), thirty-one rural and community banks (GH\$220.7 million), and three hundred and nine microfinance institutions (GH\$650 million).The following section presents a regression analysis of the foregoing data.

\subsubsection{Model Summary}

Tables 2 through 4 present results for the ANOVA. A significant aspect of a regression model is its summary; the summary presents an overall description of the regression model. Values for $\mathrm{R}, \mathrm{R}^{2}$, and Adjusted $\mathrm{R}^{2}$ are displayed in Table 2. The value of the multiple correlation coefficients between the independent variable and the dependent variable is presented in the $\mathrm{R}$ row. The $\mathrm{R}^{2}$ value in Table 3 tells us the extent to which variability in the dependent variable is accounted for by the independent variable. The $\mathrm{R}^{2}$ value $(0.2264)$ implies the affected banks and specialised deposittaking institutions account for only about $23 \%(0.226405409 \times 100 \%=22.64 \%)$ of the variation in depositors' funds. The results suggest about $77 \%(100 \%-23 \%=77 \%)$ of the outcome is explained by external random factors such as measures put in place by the Government of Ghana through the Central Bank to mitigate risks associated with depositors' funds.

\begin{tabular}{|c|c|}
\hline \multicolumn{2}{|c|}{ Regression Statistics } \\
\hline Multiple R & 0.475820774 \\
\hline R Square & 0.226405409 \\
\hline Adjusted R Square & -0.160391886 \\
\hline Standard Error & 2933473816 \\
\hline Observations & 4 \\
\hline \multicolumn{2}{|c|}{ Table 3: Summary Output } \\
\hline
\end{tabular}

Table 3 depicts an adjusted $\mathrm{R}^{2}$ value of- 0.160392 . One of the measures that determine the generalisability of the regression model is the adjusted $R^{2}$. An ideal adjusted $R^{2}$ value is closer to zero or the $R^{2}$ value. The adjusted $R^{2}$ value ($0.160392)$ is significantly different from the observed value of $R^{2}(0.226405)$ implying the cross-validity of this regression model is low; the model may not accurately predict the same dependent variable from the given independent variable in a different group of participants (Field, 2009, p. 221). The $\mathrm{R}^{2}$ significance was computed using an F-ratio. The ideal F-ratio formula for measuring $\mathrm{R}^{2}$ significance is:

$\mathrm{F}=(\mathrm{N}-\mathrm{k}-1) \mathrm{R}^{2}$

$\mathrm{k}\left(1-\mathrm{R}^{2}\right)$

Where:

$\mathrm{R}^{2}=$ Unadjusted value

$\mathrm{N}=$ Number of cases or participants in the study

$\mathrm{k}=$ Number of independent variables in the regression model

Value for the F-ratio was determined as follows:

$\mathrm{F}=(\underline{4-1-1)} 0.226405409$

$1(1-0.226405409)$

$=\underline{0.452810818}$

0.773594591

$=0.58533349$

Our computations reveal the change in the amount of variance that can be explained gives rise to an F-ratio of 0.5853 , which is equivalent to the F-value (0.5853) in Table 3. This F-ratio shows anon-significant value $(p=0.524, p$ $>0.05$ ).

\subsubsection{ANOVA}

The ANOVA helps to determine whether or not regression analysis provides better and significant prediction on the outcome than the mean. Data in Table 4 show degrees of freedom (between) of $1(2-1=1)$; degrees of freedom (within) of 2 ( 4 - $2=2)$; total degrees of freedom (df) of $3(4-1=3)$, and an F-value of 0.5853.

\begin{tabular}{|c|c|c|c|c|c|}
\hline & df & SS & MS & F & Significance F \\
\hline Regression & 1 & $5.03695 \mathrm{E}+18$ & $5.04 \mathrm{E}+18$ & 0.58533349 & 0.524179226 \\
\hline Residual & 2 & $1.72105 \mathrm{E}+19$ & $8.61 \mathrm{E}+18$ & & \\
\hline Total & 3 & $2.22475 \mathrm{E}+19$ & & & \\
\hline
\end{tabular}

Table 4: ANOVA

Data in Table 4 depict the model sum of squares (SSM) value, represented by Regression; the residual sum of squares (SSR) value, represented by Residual; the total sum of squares (SST) value, represented by Total; and the degrees of freedom (df) for each group of squares. The degree of freedom for the SS is 1, representing the independent variable. The sum of squares divided by the degrees of freedom gives us the mean squares (MS). That is, $5.03695 \div 1=5.03695=$ 5.04 . 


\subsubsection{Model Parameters}

Table 4 presents results on the parameters of the regression model. Data in the table show the coefficients, standard error, test statistic, significance, and confidence intervals for the coefficients. The coefficients in Table 4 hint us on the contribution of the independent variable to the regression model. Generally, a positive coefficient connotes a positive relationship between the independent variable and the dependent variable; a negative value symbolises a negative relationship between the two variables. Results in Table 4 show a negative coefficient value (-8960146.387). This means there is a negative relationship between banks and specialised deposit-taking institutions that are in distress and failing, and the safety of depositors' funds; the results suggest the independent variable has no significant influence on the dependent variable.

The magnitude of the t-test in Table 5 tells us the independent variable has no strong impact on the dependent variable. A standard error is identified with the coefficients in the table. The standard error shows the extent to which the coefficients would vary in different research samples (Field, 2009). The respective Upper 95\% values for the Intercept and XVariable 1 in Table 4 are 11042077665 and 41430475.16.

\begin{tabular}{|c|c|c|c|c|c|c|c|}
\hline & Coefficients & Standard Error & t Stat & P-value & Lower 95\% & Upper 95\% & Upper 95.0\% \\
\hline Intercept & 3196499005 & 1823428279 & 1.753016 & 0.22169349 & -4649079655 & 11042077665 & 11042077665 \\
\hline X Variable 1 & -8960146.387 & 11711524.2 & -0.76507 & 0.52417923 & -59350767.93 & 41430475.16 & 41430475.16 \\
\hline
\end{tabular}

\subsubsection{Report on P-Value and Confidence Interval}

Table 4 depicts $P$ value of 0.222 and negative coefficient value of -8960146.387 . These values are not significant at Alpha level $a=0.05$. The table further shows a confidence interval of -59350767.93 and 41430475.16 . The Alpha level, a priori, for this study is a $=0.05$. This implies there is a 5 per cent probability that we would be wrong; there is a 5 per cent likelihood that the population mean would not fall within the interval (Bowerman, O'Connell, and Orris, 2004; FrankfortNachmias and Nachmias, 2008). However, we are 95\% certain that our conclusions would be right. Again, the Microsoft Excel output in Table 3 show degrees of freedom (between) of $1(2-1=1)$; degrees of freedom (within) of $2(4-2=2)$; total degrees of freedom (df) of $3(4-1=3)$; and an F-ratio of 0.5853 . These values could be interpreted as:

$F(1,2)=0.5853, p>0.05$, two-tailed.

\subsubsection{Interpretation and Rejection of Alternative Hypothesis}

The foregoing results indicate banks and specialised deposit-taking institutions that are in distress and failing have no strong influence on the safety of depositors' funds. Therefore, we reject the alternative hypothesis (H1: $\mu 1 \neq \mu 2)$, and accept the null hypothesis (Ho: $\mu 1=\mu 2)$ which states that banks and specialised deposit-taking institutions that are in distress and failing have no strong effect on the safety of depositors' funds.

\section{Recommendations}

Steps taken by the Bank of Ghana to merge the five banks into one, and earlier ensure the assumption of the two banks by GCB Bank could be described as economically strategic and beneficial to the Ghanaian economy; the initiatives halted further financial exploitation of depositors by the owners, board and management of the implied banks; and prevented any negative ripple financial effect on other banks operating in the economy. Measures put in place by the Bank of Ghana are intended inter alia to ensure the safety and protection of depositors" funds against "predatory" shareholders and their related and connected parties; its initiatives are a "wake-up" call to those banking institutions with weak financial standings, but unwilling to enter into merger with other struggling banks. The research findings affirm the insignificance of the effect of distressed and failing banks and deposit-taking institutions on the safety of depositors' funds in the Ghanaian economy; the findings lend credence to the financial ingenuity of the Bank of Ghana aimed at stabilising the banking system; and enhancing its contribution to national socio-economic development and growth.

Ghana's emergence from the financial ashes with few, but quality licensed banks would serve a useful economic purpose than attempting to cling on to many, but ineffective licensed banks. Efficient and effective implementation of the following recommendations by the Bank of Ghana would rid Ghana's financial system of non-competitive and inefficient banks and specialised deposit-taking institutions; and encourage sustainable operations among competitive and productive licensed banks and specialised deposit-taking institutions across the country.

- The Bank of Ghana must have separate departments responsible for ensuring market-stability and marketintegrity of all financial institutions under its supervision. These financial institutions must be compelled to provide complete and timely disclosure of positional information to the market-stability department.

- The Bank of Ghana must establish an Insurance Reserve to be contributed to by all licensed banks and specialised deposit-taking institutions in the country. Contributions to the reserve could be prorated to reflect the category of banking or specialised deposit-taking institution. The reserve would expedite the mitigating measures of the Bank of Ghana in times of liquidity or solvency challenges of a distressed or failing bank or specialised deposit-taking institution.

- Banks and specialised deposit-taking institutions must be transparent to allow for due diligence and monitoring by the Bank of Ghana and investors. Transparency would allow the Bank of Ghana to identify grey areas that may require immediate attention; investors would identify any excessive concentration in the bank's investment portfolios, and proffer suggestions for remedies. 
- Corporate benchmarks of banks and specialised deposit-taking institutions must be preceded by due diligence and appropriate analysis; these financial institutions must focus on future opportunities, and not rely on past achievements when making strategic investment decisions.

- Management's emphasis should be on how to manage operational risk, not on investment strategy; an improved operational risk management strategy could lead to a successful investment, not the other way round. Internal controls must be improved to minimise dangers associated with operational risk.

- Financial institutions must not allow internal politics to affect their ability to address sacred cows. This would help improve on their expense management. They must seek to boost their revenues by reviewing prices of products and services on a rolling three-year basis; and by reviewing one-third of all products and services on annual basis.

- Compliance with Single Obligor limits by licensed banks across the country must be enforced, strictly, by the Bank of Ghana to improve on their capital adequacy ratios and other key operational performance indicators.

- All banks must meet the minimum capital requirement prior to licensing; at least $70 \%-80 \%$ of the minimum capital required must be met prior to the issuance of a provisional licence, and $100 \%$ during final approval.

- The powers of the Bank of Ghana in Section 56 of Act 930 must be invoked and enforced to ensure strict implementation of corporate governance framework by all licensed banks and specialised deposit-taking institutions; and assure efficiency and effectiveness in their immediate-, medium-, and long-term operations.

- Struggling banks with little or no evidence of survival must be liquidated early to avoid further financial tsunami; and to ensure financially healthy and competitive banks are maintained in the economy.

- Owners of licensed banks must engage the services of competent and skilled professionals to assure efficient dayto-day operations, effective risk management, and the eventual safety of depositors' funds. The Bank of Ghana must ensure individuals serving on the board, and especially those chairing the board of a licensed bank have the requisite expertise to do due diligence; and make informed economic decisions that would inure to the financial benefit of the bank, its depositors, and the economy as a whole.

- The Banking Supervision Department of the Bank of Ghana must be adequately staffed and resourced to enhance its effectiveness. Recommendations made by the Banking Supervision Department after examination of banks and specialised deposit-taking institutions must be given strong considerations and implemented by the Governor to help maintain a strong banking sub-sector that would appeal, especially to foreign investors.

- Licensed banks that are struggling to meet the minimum capital requirement of GH\$400 million by December 2018 must engage in voluntary and strategic mergers. A strategic merger refers to the consolidation of two or more banks after careful considerations, and determining their branch networks are not clustered in terms of proximity. This would help prevent bank-branch closures, and minimise the tendency to lay off staff as a result of mergers.

- Banks must diversify their assets and strategies to reduce excessive concentration in their investment portfolios; and minimise risk associated therein. Complete elimination of risk may not be possible; without risk, a reward may not exist. However, risk could be managed to limit its negative impact on operations.

- Investors must shift their focus from assessing financial statements to evaluating non-financial aspects such as management competence, operational risk management, among others, to minimise the level of investment loss in the financial sub-sector in general. The foregoing implies investors must not begin and end due investment diligence with review of financial records; it must transcend to include critical and technical analysis of management performance and corporate governance.

- There is a difference between management accounting statements and financial accounting statements; investors must always strive for a copy of the former, not the latter. Investors must not always rely on past records as a basis for assuring higher returns in future.

- The Bank of Ghana must review some of its existing regulatory measures where necessary to ensure conformity to international banking supervision and operational standards. It must ensure strict adherence to its regulatory measures by all licensed banks and specialised deposit-taking institutions operating within its jurisdiction, going forward.

\section{References}

i. Abdullah, M. (2015). An empirical analysis of liquidity, profitability and solvency of Bangladeshi banks. Journal of Business and Financial Affairs, 5, 157. DOI: 10.4172/ 2167-0234.1000157

ii. Ashley, E. (2013). Principles of Corporate Finance Theory: Theory with a Practical Dimension. Create Space Independent Publishers. Charlotte, SC.: USA

iii. Ashley, E. M., Takyi, H., \& Obeng, B. (2016). Research Methods: Quantitative and Qualitative Approaches to Scientific Inquiry. Accra: The Advent Press.

iv. Bank of Ghana. (2007). Banking and Financial Laws of Ghana 1998-2006. I.D.P.S. Department, Bank of Ghana.

v. Bank of Ghana. (2009). Banking and Financial Laws of Ghana 2006-2008. I.D.P.S. Department, Bank of Ghana.

vi. Bank of Ghana. (2016a).Bank of Ghana (Amendment) Act, 2016 (Act 918).Accra: GPCL, Assembly Press.

vii. Bank of Ghana. (2016b). Banks and Specialised Deposit-Taking Institutions Act of 2016, Act 930. Accra: GPCL, Assembly Press.

viii. Bank of Ghana. (2018). Banking Acts - Bank of Ghana. Retrieved from https:/ / www.bog.gov.gh 
ix. Basel Committee on Banking Supervision. (2011). Operational Risk - Supervisory Guidelines for the Advanced Measurement Approaches. Basel, Switzerland: Bank for International Settlements.

x. Bowerman, B. L., \& O'Connell, R.T. (1990). Linear Statistical Models: An Applied Approach (2nd ed.). Belmont, CA: Duxbury.

xi. Deans, G. K., Kroeger, F., and Zeisal, S. (2003). Winning the Merger Endgame. NY: McGraw-Hill

xii. Field, A. (2009). Discovering Statistics Using SPSS(3rd ed.). London: Sage.

xiii. Frankfort-Nacmias, C. \& Nachmias, D. (2008). Research Methods in the Social Sciences (7th ed.). USA.: Worth Publishers.

xiv. Hassan, M. (2018). Evidence determination of bank failure eradication in the $21^{\text {st }}$ century Nigeria. Journal of Business and Financial Affairs, 7(2), 341. DOI: 10.4172/ 2167-0234.1000341

xv. Kalpic, B. (2008). Why bigger is not always better: The strategic logic of value creation through M\&As. The Journal of Business Strategy, 29(6), 4

xvi. Lu, W. \& Whidbee, D. A. (2013). Bank structure and failure during the financial crisis. Journal of Financial Economic Policy, 5(3). DOI: 10.1108/JFEP-02-2013-0006

xvii. Markowitz, H. M. (2005). Market Efficiency: A Theoretical Distinction and So What? Financial Analyst Journal, 61 (5), 17-30 (AN 18486601)

xviii. Markowitz, H. M. (1987). Mean-Variance Analysis in Portfolio Choice and Capital Markets. Oxford, U.K.: Basil Blackwell

xix. Mulbert, P. O. (2009). Corporate governance of banks after the financial crisis - Theory, evidence, reforms. SSRN Working Paper Series

xx. Nicholas, S. and Forsythe, G. (2008). SFAS No. 141(R): How much preparation do you need before your exit M\&A deal? Corporate Finance Review, 12 (6), 27-29

xxi. Santacruz, L. (2009). Effect of general economic mood on investor risk tolerance - Implications For financial planning. JASSA, 35-42

xxii. Sharpe, W. F. (1964). Capital Asset Prices: A Theory of Market Equilibrium under Conditions of Risk. Journal of Finance, 19 (3), 425-442

xxiii. Sharpe, W. F. (1991). Capital Asset Prices with and without Negative Holdings. Journal of Finance, 46 (2), 489-509 (AN 4653227)

xxiv. Sheth, J. and Sisodia, R. (2002).The Rule of Three Surviving and Thriving in Competitive Markets. NY: The Free Press

xxv. Vizjak, A. (2008). Competing Against Scale: The Growth Cube for Scale-based Competition. GV Publishing 